\title{
Implications of immune-inflammatory responses in smooth muscle dysfunction and disease
}

\author{
Fumitake USUI-KAWANISHI ${ }^{1,2}$, Masafumi TAKAHASHI ${ }^{2}$, Hiroyasu SAKAI ${ }^{3}$, \\ Wataru $\mathrm{SUTO}^{4}$, Yuki KAI ${ }^{3}$, Yoshihiko $\mathrm{CHIBA}^{4}$, Keizo HIRAISHI ${ }^{5}$, \\ Lin Hai KURAHARA ${ }^{5,6}$, Masatoshi HORI ${ }^{7}$ and Ryuji INOUE 5 \\ ${ }^{1}$ Division of Biopharmaceutical Engineering, Department of Pharmaceutical Engineering, \\ Toyoma Prefectural University, 5180 Kurokawa, Imizu-shi, Toyama 939-0398, Japan \\ ${ }^{2}$ Division of Inflammation Research, Center of Molecular Medicine, Jichi Medical University, \\ 3311-159 Yakushiji, Shimono-shi, Tochigi 329-0498, Japan \\ ${ }^{3}$ Department of Analytical Pathophysiology, Hoshi University, 2-4-41 Ebara, Shinagawa-ku, \\ Tokyo 142-8501, Japan \\ ${ }^{4}$ Department of Physiology and Molecular Sciences, Hoshi University, 2-4-41 Ebara, Shinagawa- \\ ku, Tokyo 142-8501, Japan \\ ${ }^{5}$ Department of Physiology, Fukuoka University School of Medicine, 7-45-1 Nanakuma, Jonan-ku, \\ Fukuoka 814-0180, Japan \\ ${ }^{6}$ Department of Cardiovascular Physiology, Faculty of Medicine, Kagawa University, 1750-1 \\ Ido, Miki-machi, Kida-gun, Kagawa 761-0793, Japan \\ ${ }^{7}$ Department of Veterinary Pharmacology, Graduate School of Agricultural and Life Sciences, \\ The University of Tokyo, 1-1-1 Yayoi, Bunkyo-ku, Tokyo 113-8657, Japan
}

Submitted August 18, 2019; accepted in final form December 20, 2019

\begin{abstract}
In the past few decades, solid evidence has been accumulated for the pivotal significance of immunoinflammatory processes in the initiation, progression, and exacerbation of many diseases and disorders. This groundbreaking view came from original works by Ross who first described that excessive inflammatory-fibroproliferative response to various forms of insult to the endothelium and smooth muscle of the artery wall is essential for the pathogenesis of atherosclerosis (Ross, Nature 1993; 362(6423): 801-9). It is now widely recognized that both innate and adaptive immune reactions are avidly involved in the inflammation-related remodeling of many tissues and organs. When this state persists, irreversible fibrogenic changes would occur often culminating in fatal insufficiencies of many vital parenchymal organs such as liver, lung, heart, kidney and intestines. Thus, inflammatory diseases are becoming the common life-threatening risk for and urgent concern about the public health in developed countries (Wynn et al., Nature Medicine 2012; 18(7): 1028-40). Considering this timeliness, we organized a special symposium entitled "Implications of immune/inflammatory responses in smooth muscle dysfunction and disease" in the 58th annual meeting of the Japan Society of Smooth Muscle Research. This symposium report will provide detailed synopses of topics presented in this symposium; (1) the role of

Corresponding authors: Fumitake Usui-Kawanishi, Division of Biopharmaceutical Engineering, Department of Pharmaceutical Engineering, Toyoma Prefectural University, Toyama, Japan; Hiroyasu Sakai, Department of Analytical Pathophysiology, Hoshi University; Yoshihiko Chiba, Department of Physiology and Molecular Sciences, Hoshi University; Lin-Hai Kurahara, Department of Cardiovascular Physiology, Kagawa University; Ryuji Inoue, Department of Physiology, Fukuoka University School of Medicine

(C)2019 The Japan Society of Smooth Muscle Research
\end{abstract}


inflammasome in atherosclerosis and abdominal aortic aneurysms by Fumitake Usui-Kawanishi and Masafumi Takahashi; (2) Mechanisms underlying the pathogenesis of hyper-contractility of bronchial smooth muscle in allergic asthma by Hiroyasu Sakai, Wataru Suto, Yuki Kai and Yoshihiko Chiba; (3) Vascular remodeling in pulmonary arterial hypertension by Keizo Hiraishi, Lin Hai Kurahara and Ryuji Inoue.

Key words: atherosclerosis, inflammasome, bronchial asthma, hypersensitivity, pulmonary hypertension

\section{(1) The role of inflammasome in atherosclerosis and abdominal aortic aneurysms}

\section{Brief Synopsis}

In recent years, much attention has been paid to the fact that chronic inflammation contributes to lifestyle-related diseases such as hyperlipidemia, obesity, diabetes mellitus and hypertension. In this study, we attempted to elucidate the role of the NLRP3 inflammasome in the sterile inflammation underlying atherosclerosis and aortic aneurysms. Our findings suggest that caspase-1 plays critical roles in vascular inflammation and atherosclerosis. We also show the evidence for the importance of the NLRP3 inflammasome in initial inflammatory responses in abdominal aortic aneurysms. The NLRP3 inflammasome is thus expected to be a therapeutic target for the progression of atherosclerosis and abdominal aortic aneurysms and a good clue to clarifying the mechanism involved therein.

\section{Introduction}

Recently, the importance of inflammation has been recognized in the pathogenesis of cardiovascular diseases, such as atherosclerosis, ischemic heart disease and heart failure (1). The inflammation in these diseases does not involve infectious agents, thus being called sterile inflammation. However, the molecular basis for sterile inflammatory responses remains largely unclear. Therefore, we focused on the innate immune system, in particular, the NLRP3 inflammasome. The NLRP3 inflammasome is a large multi-protein complex in the cytosol and contains three components, the Nod-like receptor NLRP3, the adaptor protein ASC and the interleukin (IL)-1 $\beta$ converting enzyme, caspase-1 (1-3). When the cell senses sterile danger signals such as extracellular ATP, monosodium urate crystals MSU and hyaluronic acid, these three components assemble to form the inflammasome. Activation of capase-1 induces processing of IL-1 $\beta$. Secretion of a mature form of IL-1 $\beta$ initiates sterile inflammation. Clinical and experimental studies have shown that IL-1 $\beta$ is important in the pathogenesis of atherosclerosis $(4,5)$. Abdominal aortic aneurysm (AAA) is thought to be a chronic inflammatory disease characterized by atherosclerotic changes where infiltrating macrophages release matrix metalloproteinases (MMPs) that degrade extracellular matrix components including collagen and elastin (6-8). Therefore, we hypothesized that the NLRP3 inflammasome may be a key mediator of initial inflammation in atherosclerosis and AAA progression.

\section{Results and Discussion}

\section{Atherosclerosis}

To investigate whether the NLRP3 inflammasome is critical for the development of atherosclerosis, we used ApoE deficient mice fed with western diet for 12 weeks because they exhibit severe hypercholesterolemia and are an excellent model for human atherosclerosis (9). Sudan IV staining revealed that atherosclerotic 
plaque areas in the whole aorta of ApoE and caspase-1 double deficient mice were significantly decreased compared to mice solely deficient in ApoE. Cross-sectional staining with Oil Red $\mathrm{O}$ and immunohistochemical analyses of aortic roots also showed that the plaques and infiltration of macrophages were significantly reduced by caspse-1 deficiency.

To further explore the role of caspase-1, we examined whether calcium phosphate crystals can activate the inflammasome in macrophages in vitro because it is known that vascular calcification actively participates in plaque progression and instability via its actions on macrophages (10). Activation of the inflammasome via caspase-1 activation by TCP and MSU crystals was confirmed by a fluorescent cell permeable probe (FLICA assay) that specifically binds to activated caspase-1 in J774 macrophages. Similar to MSU crystals, TCP crystals also stimulated a dose-dependent release of IL-1 $\beta$. Because lysosomal destabilization and cathepsin B activation have been shown to mediate the inflammasome activation in response to cholesterol crystals (11, 12), we tested the effects of bafilobycin, an inhibitor of lysosomal acidification, and CA-074 Me, a specific cathepsin B inhibitor. Treatment with these inhibitors significantly decreased TCP crystal-induced IL-1 $\beta$ release. Collectively, our findings suggest that inflammasomes play a critical role in vascular inflammation and atherosclerosis (13).

\section{Abdominal aortic aneurysms}

We first investigated inflammatory responses and ASC expression in tissues from human abdominal aortic aneurysms (AAA). ASC expression and inflammatory cell infiltration (mainly CD68 positive macrophages) were clearly visible in the adventitia. Furthermore, double-immuno-fluorescence staining revealed the colocalization of ASC with CD68 positive macrophages. These data were suggested the role of the inflammasome in the process of AAA formation. Next, to further clarify the role of inflammasomes, we infused ApoE deficient, ApoE and NLRP3 or ASC or caspase-1 double deficient mice either with vehicle or angiotensin II (AII; 1,000 $\mathrm{ng} / \mathrm{kg}$ per minute) for 28 days because AII-infused ApoE deficient mice are widely used to investigate the pathogenesis of an induced abdominal aortic aneurysm (AAA) model (7, 14). As expected, the systolic blood pressure was elevated at 28 days after AII infusion. AAA was formed in about $70 \%$ of ApoE deficient mice. In contrast, only 15 to $20 \%$ of mice deficient in the inflammasome components showed AAA formation. The maximal aortic diameter measured from these mice was also significantly smaller than that in ApoE alone deficient mice. A quantitative RT-PCR analysis showed that the mRNA levels of inflammatory cytokines (Ill $\beta$, Il6, and Ccl2) and fibrosis factors (Mmp2, Mmp9, Timp1, Colla1, and Col3al) were elevated in the AAA tissues from ApoE deficient mice, whereas these elevations were lesser in those deficient in the inflammasome-associated molecules. These findings suggest that the inflammasome mediates inflammatory and fibrotic responses in the process of AAA formation. To clarify the role of the inflammasome in AAA development, we assessed the plasma IL-1 $\beta$ level. The plasma IL-1 $\beta$ level was elevated in ApoE deficient mice after AII infusion, and this elevation was significantly decreased in the inflammasome component molecule deficient mice. Interestingly, in an early time course after AII infusion (7 days), the plasma IL-1 $\beta$ level was markedly higher than that at 28 days in the ApoE deficient mice. This elevation was also completely abrogated in the inflammasome component molecule deficient mice. Thus, we tried a detailed analysis by using a short-term 7-day model.

At 7 days after AII infusion, no morphological change was observed in the suprarenal aortas between ApoE- and Caspase-1-deficient mice. However, interestingly, histological analysis revealed that disrupted elastic lamellae and intramural hemorrhages were clearly visualized in the vascular walls of ApoE-deficient mice. These changes were not observed in caspase-1 deficiency. Messenger RNAs of inflammatory cytokines and fibrosis factors were elevated in the suprarenal aortae from ApoE deficient mice, whereas they were decreased 
in those from caspse-1 deficient mice. These results suggest that inflammation and degradation of elastic lamina were induced in the early phase of AAA formation via the inflammasome activation. To investigate the role of macrophages, vascular smooth muscle cells, and fibroblasts in the initiation of AAA formation, we performed immunohistochemical analysis and found that, in the early phase of AAA formation, macrophages were mainly accumulated in the adventitia in ApoE deficient mice. This accumulation was reduced in caspsae-1 deficient mice. In addition, ASC was highly expressed in adventitial macrophages suggesting the role of the inflammasome in the initiation of AAA formation. Recently, the generation of mitochondrial reactive oxygen species (mtROS) has been shown to activate the inflammasome (15-17). Therefore, we next determined whether mtROS was generated in the ApoE deficient mice by using MitoSOX, DHE and MitoTracker. Accumulation of mtROS was clearly visualized in the adventitia, however, this was less prominent in caspase-1 deficient mice. This accumulation was further confirmed by the finding that pretreatment with ROS scavenger Tiron completely diminished mtROS accumulation. Furthermore, in situ zymography showed that MMPs activities were increased in the adventitia of ApoE deficient mice, whereas this increased activity was suppressed in caspase-1 deficient mice. These results demonstrate that the inflammasome and MMPs were activated in the adventitial macrophages during the initiation of AAA formation where mitochondrial ROS may mediate the inflammasome activation.

To further investigate the molecular mechanisms by which AII activates the inflammasome in macrophages, we used a macrophage cell line J774 and bone marrow-derived macrophages (BMDMs) in vitro. We first confirmed the expression of the main AII receptors, AT1R and AT2R, in both types of macrophages. To investigate the inflammasome activation, we primed the cells with a low dose of lipopolysaccharide to ensure the induction of pro-IL-1 $\beta$, as described in previous studies $(18,19)$. AII caused a dose-dependent release of IL-1 $\beta$ in J774 cells. The ability of AII to stimulate IL-1 $\beta$ release was also confirmed in BMDMs, which was completely inhibited in those from mice deficient in inflammasome-associated molecules. Furthermore, the selective AT1R antagonist losartan, but not the selective AT2R antagonist PD123319, significantly inhibited AII induced IL-1 $\beta$ release. These findings demonstrate that in macrophages, AII activates the inflammasome through an AT1R-dependent pathway. Next, we investigated the possible involvement of mtROS, because mtROS was increased in the adventitial macrophages in the early phase of AAA formation, we hypothesized that in macrophages, AII activates the inflammasome via mtROS production. AII clearly induced mtROS production in a time dependent manner, and this was completely prevented by treatment with the AT1R inhibitor losartan. These data indicate that AII induces mtROS production via the AT1R-signaing pathway. To corroborate this idea, we tested the mtROS inhibitors, Cyclosporin A and MitoTEMPO. These inhibitors significantly inhibited IL-1 $\beta$ release induced by AII treatment. Further, we determined the involvement of caspase-1 activity by using the FLICA assay. AII induced caspase-1 activation was inhibited by cyclosporin A. Finally, we observed that activation of MMP by AII was inhibited by cyclosporin A and losartan. These results collectively suggest that AII induces mtROS production, which in turn causes inflammasome activation and then MMP activation (20).

\section{Conclusion}

The major findings of this study indicate that the NLRP3 inflammasome is an essential mediator of atherosclerosis and AAA formation, and that this inflammasome activation is mediated by lysosomal destabilization and mtROS production in the macrophages (Fig. 1). Increasing evidence indicates that inflammation is a major contributing factor to the progression of atherosclerosis and AAA. However, the exact mechanisms underlying inflammation and its involvement in atherosclerosis and AAA formation remain unknown. The re- 


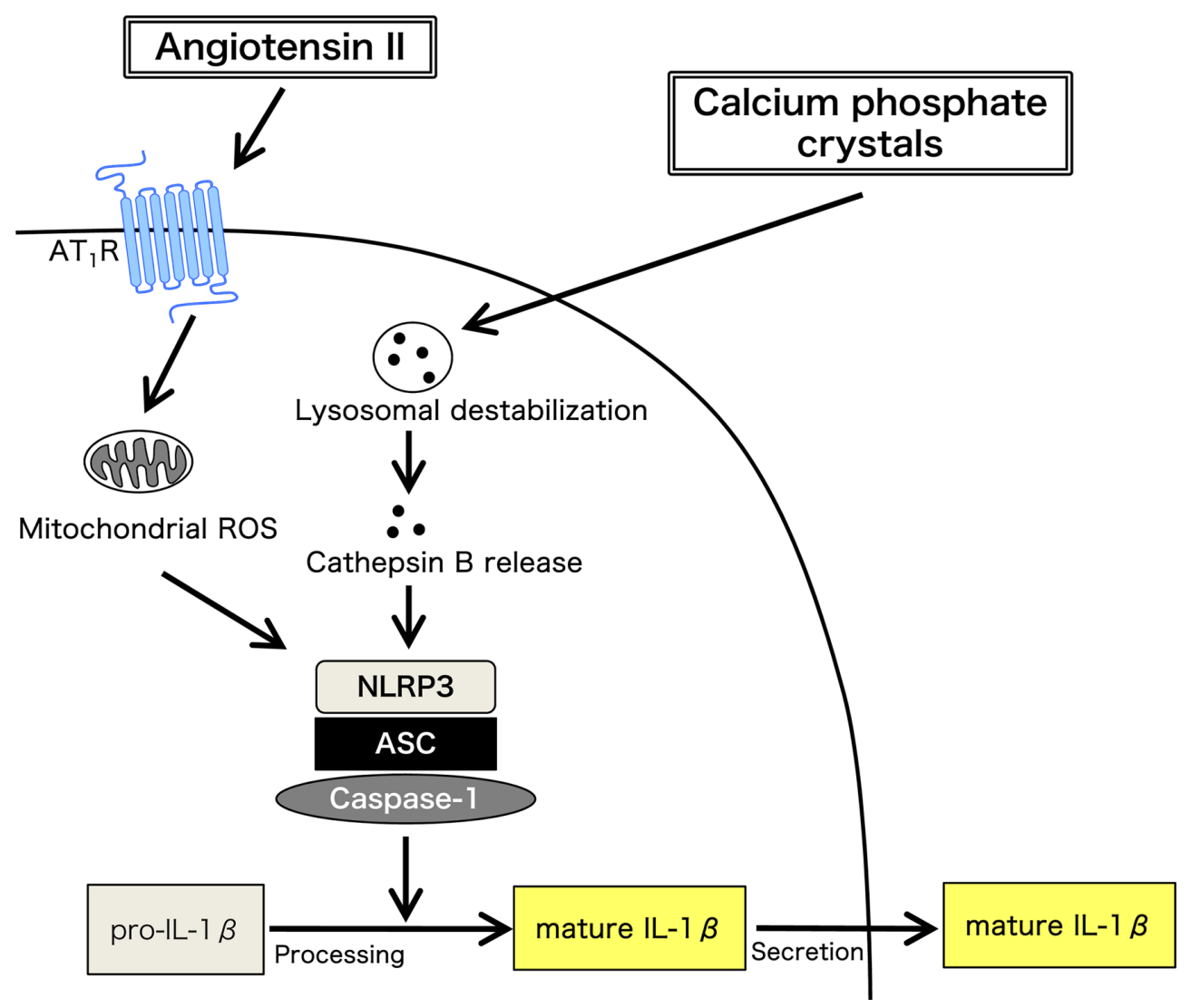

Fig. 1. The activation pathway of the NLRP3 inflammasome by Angiotensin II and calcium phosphate crystals.

sults of the present study clearly demonstrated direct links of NLRP3 inflammasome activation to atherosclerosis and AAA progression. Furthermore, our results clarify the molecular events underlying the inflammation involved in atherosclerosis and AAA formation and suggest that the NLRP3 inflammasome is a potential novel therapeutic target for atherosclerosis and AAA progression.

\section{(2) Mechanisms underlying the pathogenesis of hyper-contractility of bronchial smooth muscle in allergic asthma}

\section{Brief Synopsis}

Airway hyperresponsiveness (AHR) and inflammation are key pathophysiological features of asthma. Enhanced contraction of bronchial smooth muscle (BSM) is one of the causes of the AHR. It is thus important for the development of asthma therapy to understand the change in the contractile signaling of airway smooth muscle cells associated with the AHR. In addition to the $\mathrm{Ca}^{2+}$-mediated phosphorylation of myosin light chain (MLC), contractile agonists also enhance the MLC phosphorylation level to a larger extent than that caused solely by $\mathrm{Ca}^{2+}$ via inhibition of MLC phosphatase (MLCP) in various types of smooth muscle including airway smooth muscle. This phenomenon is called $\mathrm{Ca}^{2+}$ sensitization of contraction. To date, involvements of RhoA/ ROCKs and PKC/Ppp1r14a (also called as CPI-17) pathways in the $\mathrm{Ca}^{2+}$ sensitization have been identified. Our previous studies revealed that the agonist-induced $\mathrm{Ca}^{2+}$ sensitization of contraction is markedly augmented in BSM of animal models of allergen-induced AHR. In BSM of these animal models, the expression of RhoA and CPI-17 proteins were significantly increased, indicating that both the $\mathrm{Ca}^{2+}$ sensitizing pathways are augment- 
ed. Interestingly, incubation of BSM cells with asthma-associated cytokines, such as interleukin-13 (IL-13), IL-17, and tumor necrosis factor- $\alpha$ (TNF- $\alpha$ ), caused up-regulations of RhoA and CPI-17 in BSM cells of naive animals and cultured human BSM cells. In addition to the transcription factors such as STAT6 and NF- $\mathrm{KB}$ activated by these inflammatory cytokines, an involvement of down-regulation of miR-133a, a microRNA that negatively regulates RhoA translation, has also been suggested in the IL-13- and IL-17-induced up-regulation of RhoA. Thus, the $\mathrm{Ca}^{2+}$ sensitizing pathways and the cytokine-mediated signaling including microRNAs in BSMs might be potential targets for treatment of allergic asthma, especially the AHR.

Key words: bronchial asthma, airway hyperresponsiveness, $\mathrm{Ca}^{2+}$ sensitization, RhoA, CPI-17 (Ppp1r14a)

\section{Introduction}

Pathophysiology of allergic asthma is characterized by the combination of airway hyperresponsiveness (AHR), inflammation, and remodeling (21-23). The AHR is defined by increased airway narrowing in response to a wide range of stimuli, and is responsible for recurrent episodes of wheezing and breathlessness. Enhanced bronchial smooth muscle (BSM) contraction is one of the causes of AHR. In addition, the AHR correlates with the severity of asthma (24) and with the amount of treatment needed to control symptoms (25). The severity of hyperresponsiveness is associated with severer symptoms and a steeper fall in forced expiratory volume in 1 second $\left(\mathrm{FEV}_{1}\right)(26)$.

Allergic asthma is a Th2 lymphocyte-mediated inflammatory airway disease. Cytokines derived from Th2 lymphocytes play a key role in the pathophysiology of asthma through the induction of eosinophilic airway inflammation. These lead to variable airway obstruction and AHR to nonspecific stimuli (27). The $\beta$-adrenergic drugs are the most potent dilators of BSM currently approved for clinical use against asthma. Among the $\beta$-adrenergic agonists, the individual agents vary in their rapidity of onset and action duration. Inhaled, short-acting, selective $\beta_{2}$-adrenergic agonists (SABAs) are the mainstay of acute asthma therapy, whereas inhaled, long-acting, selective $\beta_{2}$ adrenergic agonists (LABAs), in combination with inhaled glucocorticoids, play a role in long-term control of moderate to severe asthma. Rapid relief from airway limitation in asthmatic patients by SABA inhalation suggests the involvement of augmented airway smooth muscle contraction in the airway obstruction. Thus, it is important to understand the changes in the contractile signaling of airway smooth muscle cells associated with AHR for the development of asthma therapy. In this review, we will describe the pathophysiological mechanisms of augmented BSM contraction in AHR.

In addition, it is worthy to mention here that all animal experiments were done according to the guiding principles for the care and use of laboratory animals approved by the Animal Care Committee of Hoshi University (Tokyo, Japan).

\section{Involvement of Augmented $\mathrm{Ca}^{2+}$ Sensitization in BSM Hyper-Contraction in Allergic Asthma}

To elucidate the pathogenesis of allergic bronchial asthma, various animal models have been used by investigators including us. In an allergic asthma model using rats (28), that were actively sensitized with 2,4-dinitrophenylated Ascaris suum extract antigen and repeatedly challenged with aerosolized antigen, a marked augmentation of airway responsiveness to inhaled acetylcholine (ACh), i.e., the AHR, was observed (Fig. 2A). In this animal model of asthma, the ACh responsiveness of the isolated BSM was also enhanced significantly (Fig. 2B). Similarly, in a mouse model of allergic asthma in which ovalbumin was used as an antigen, both the in vivo AHR and the in vitro BSM hyperresponsiveness have also been shown $(29,30)$. These observations remind us of an idea that the hyper-contractility of BSM per se is a cause of the AHR. Indeed, the 


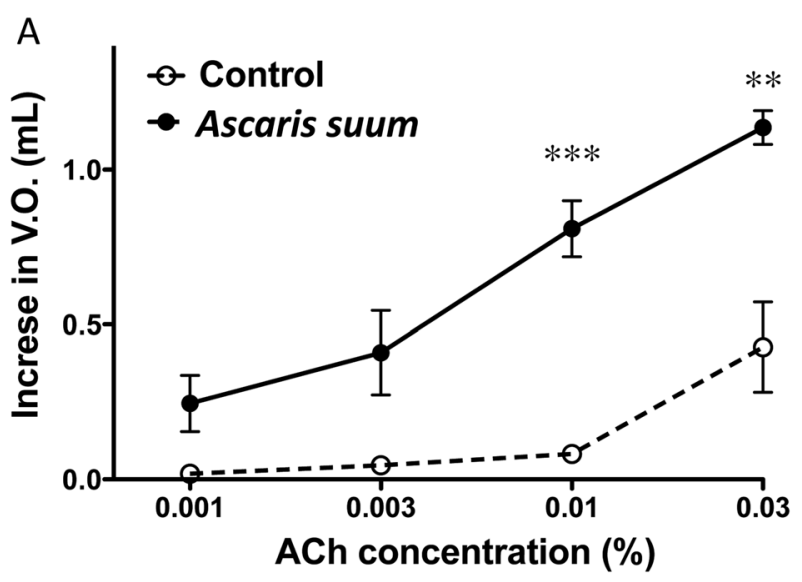

from Fig.1C (Misawa and Chiba, 1993; ref.30)

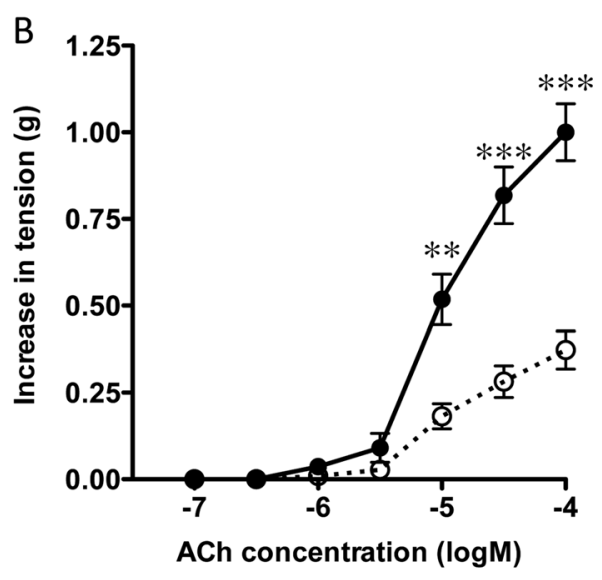

from Fig.3C (Misawa and Chiba, 1993; ref.30)

Fig. 2. Repeated antigen challenge-induced airway hyperresponsiveness in vivo and in vitro. (A) Dose-response curves of the bronchomotor response to aerosolized acetylcholine (ACh) after repeated challenges with antigen in anesthetized rats. (B) Dose-response curves of contractile responses of isolated bronchi to ACh after repeated challenges with antigen (Asc) or saline (Sal) inhalation by sensitized rats. ${ }^{* *} P<0.01$ and $* * * P<0.001$ vs. Control. ॰: Control, $\bullet$ : Repeated challenges with antigen.

hyperresponsiveness of airway smooth muscle was also suggested in asthmatics (31). At least, the BSM hyperresponsiveness to ACh observed in the antigen-induced AHR animals is not explained simply by changes in its receptor number: no significant difference in the muscarinic receptor density was observed between the AHR and control animals (32). Furthermore, the ACh-mediated increase in cytosolic $\mathrm{Ca}^{2+}$ concentration measured using the Fura-2-loaded BSM was within normal level whereas the contraction induced by ACh was much enhanced in the AHR animals (33).

We have tried to uncover the mechanism of the BSM hyperresponsiveness in allergic asthma. Figure 2 suggest that the agonist-induced $\mathrm{Ca}^{2+}$ sensitization of contraction may be augmented in BSM of the AHR animals (34). In BSM that were pre-incubated with $\mathrm{ACh}\left(10^{-3} \mathrm{M}\right)$ under $\mathrm{Ca}^{2+}$-free condition (in the presence of $10^{-6} \mathrm{M}$ nicardipine and $0.05 \mathrm{mM}$ EGTA), addition of $\mathrm{Ca}^{2+}$ induced a concentration-dependent contraction (Fig. $3 \mathrm{~A})$. The contractile response to $\mathrm{Ca}^{2+}$ of the ACh-stimulated BSM isolated from the OA-challenged mice was markedly augmented as compared to that from the sensitized control animals. By contrast, no significant difference in the response to $\mathrm{Ca}^{2+}$ of BSM depolarized with $60 \mathrm{mM} \mathrm{K}^{+}$(in the absence of nicardipine and presence of $0.05 \mathrm{mM}$ EGTA and $10^{-6} \mathrm{M}$ atropine) was observed between the groups (Fig. 3B). These findings suggest that, although the contraction mediated by $\mathrm{Ca}^{2+}$ itself is not changed, the ACh-mediated contractile signaling independent of cytosolic $\mathrm{Ca}^{2+}$ concentration, i.e., $\mathrm{Ca}^{2+}$ sensitization of contraction, is augmented in BSM of the AHR animals. To confirm it in more detail, the BSM contractility was also determined by using $\alpha$-toxinpermeabilized BSM preparations in mice (29). Application of free $\mathrm{Ca}^{2+}$ induced a concentration-dependent reproducible contractile response, indicating successful permeabilization. As shown in Fig. 3C, when the $\mathrm{Ca}^{2+}$ concentration was clamped at pCa 6.0, application of ACh $\left(10^{-5}-10^{-3} \mathrm{M}\right)$ in the presence of GTP $\left(10^{-4} \mathrm{M}\right)$ caused a further contraction, i.e., $\mathrm{ACh}$-induced $\mathrm{Ca}^{2+}$ sensitization, in an $\mathrm{ACh}$ concentration-dependent manner. The ACh-induced $\mathrm{Ca}^{2+}$ sensitization was significantly greater in BSM of the AHR mice as compared to those of control animals (Fig. 3D). Similar results were also obtained when a rat model of antigen-induced AHR was used (35). It is thus strongly suggested that the $\mathrm{Ca}^{2+}$ sensitization of contraction is augmented in BSM of the AHR animals. 
A

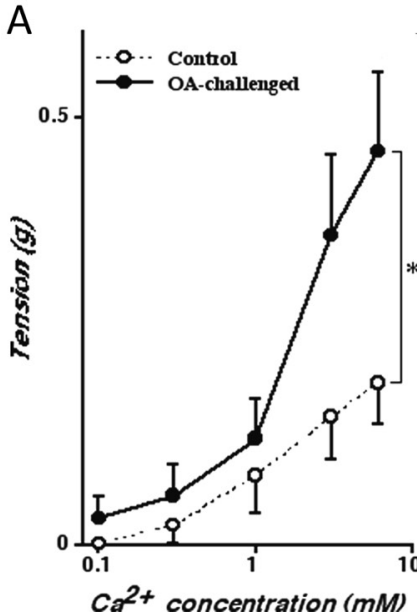

B

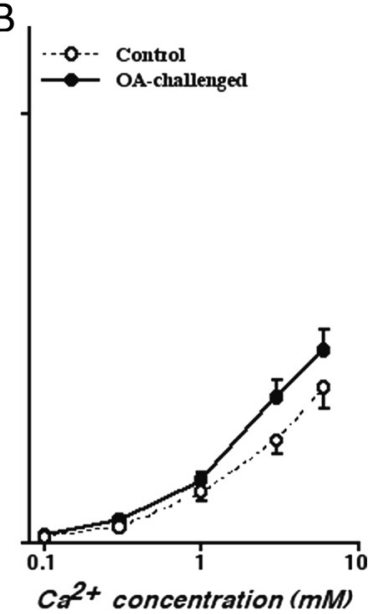

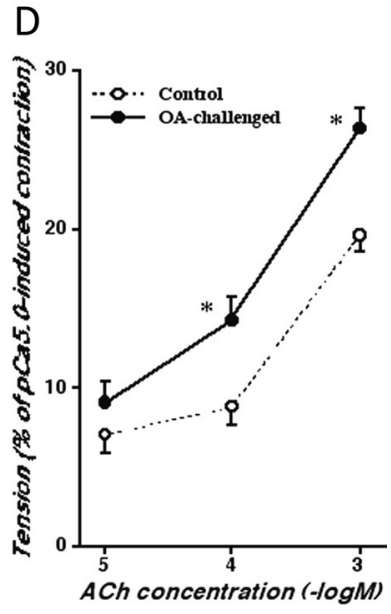

Fig. 3. Cumulative dose-response curves to $\mathrm{Ca}^{2+}$ of bronchial rings obtained from sensitized control (Control; open circles) and repeatedly ovalbumin-challenged (OA-challenged; closed circles) mice. Bronchial rings were preincubated with $10^{-3} \mathrm{M}$ acetylcholine (ACh) in the presence of $10^{-6} \mathrm{M}$ nicardipine (A), or with isotonic $60 \mathrm{mM} \mathrm{K}^{+}$ in the presence of $10^{-6} \mathrm{M}$ atropine (B) in a $\mathrm{Ca}^{2+}$-free, $0.05 \mathrm{mM}$ EGTA solution. The $\mathrm{Ca}^{2+}$-induced contraction of the ACh-stimulated BSM was significantly augmented in the OA-challenged group (A; $P<0.05)$, whereas no significant change in the $\mathrm{Ca}^{2+}$-induced contraction of the high $\mathrm{K}^{+}$-depolarized muscle was observed between the groups (B). (C) ACh-induced $\mathrm{Ca}^{2+}$ sensitization of murine BSM. A representative recording of a contraction induced by $\mathrm{Ca}^{2+}\left(\mathrm{pCa} 6.0\right.$ and 5.0) and $\mathrm{ACh}\left(10^{-5}-10^{-3} \mathrm{M}\right)$ with guanosine triphosphate (GTP; $\left.10^{-4} \mathrm{M}\right)$ in $\alpha$-toxinpermeabilized BSM isolated from a sensitized control mouse. In the presence of GTP, ACh induced further contractions even in a constant $\mathrm{Ca}^{2+}$ concentration of $\mathrm{pCa}$ 6.0, i.e., ACh induced $\mathrm{Ca}^{2+}$ sensitization, in an $\mathrm{ACh}$ dose-dependent manner. (D) Dose-response curves of ACh $\left(10^{-5}-10^{-3} \mathrm{M}\right)$-induced $\mathrm{Ca}^{2+}$ sensitization of $\alpha$-toxinpermeabilized BSM isolated from sensitized control (Control; open circles) and repeatedly ovalbumin-challenged (OA-challenged; closed circles) mice. ${ }^{*} P<0.05$ vs. Control group.

\section{RhoA/ROCK Pathway as a Therapeutic Target of Asthma}

Increased bronchial tone plays an important role in the pathophysiology of airway diseases including asthma. Bronchial tone is mainly regulated by the contraction of BSM cells (BSMCs). Smooth muscle contraction is mediated by the phosphorylation of the regulatory myosin light chain (MLC). The MLC phosphorylation level increases when MLC kinase (MLCK) is activated, whereas the level decreases when MLC phosphatase (MLCP) is activated (36). MLCP dephosphorylates MLC, leading to the smooth muscle relaxation (37). The MLCP activity is highly regulated both by contraction and relaxation signaling pathways. A monomeric GTPase, RhoA, plays a key role in the $\mathrm{Ca}^{2+}$ sensitization of contraction in smooth muscle. Contractile agonists, such as G protein-coupled receptor (GPCR) agonists, have an ability to activate RhoA. The precise nature of the activation of RhoA by GPCR is not yet uncovered but involves guanine nucleotide exchange factors RhoGEFs, such as p115RhoGEF, PDZ-RhoGEF and LARG (38). The RhoGEFs activate RhoA by exchanging GDP- to GTP-bound form of RhoA (39). The activated GTP-bound form of RhoA activates its downstream ROCKs (40-42), which in turn phosphorylates myosin phosphatase targeting protein (MYPT), leading to an inhibition of MLCP activity (43). When the MLC phosphatase is inhibited, the phosphorylated MLC cannot be dephosphorylated, resulting in a promotion of the contractile state, that is $\mathrm{Ca}^{2+}$ sensitization of smooth muscle contraction.

As described above, the ACh-induced $\mathrm{Ca}^{2+}$ sensitization was significantly augmented in BSM of mice with allergic asthma. The augmented $\mathrm{Ca}^{2+}$ sensitization was sensitive to Clostridium botulinum $\mathrm{C} 3$ exoenzyme, an inhibitor of RhoA, and Y-27632, an inhibitor of ROCK $(35,44)$, indicating that the RhoA/ROCK pathway is involved in the $\mathrm{Ca}^{2+}$ sensitizing signaling. Interestingly, protein expression of RhoA in BSM was 
A

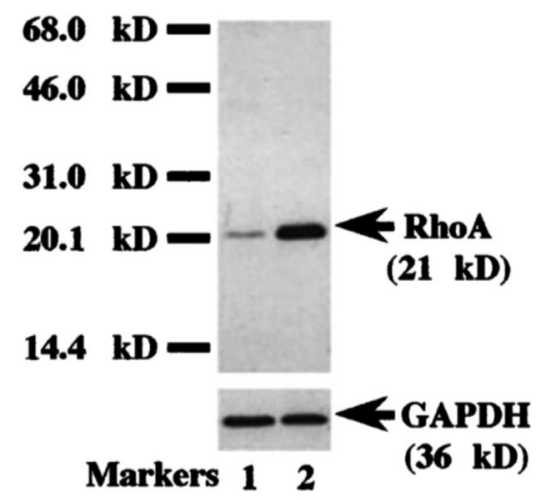

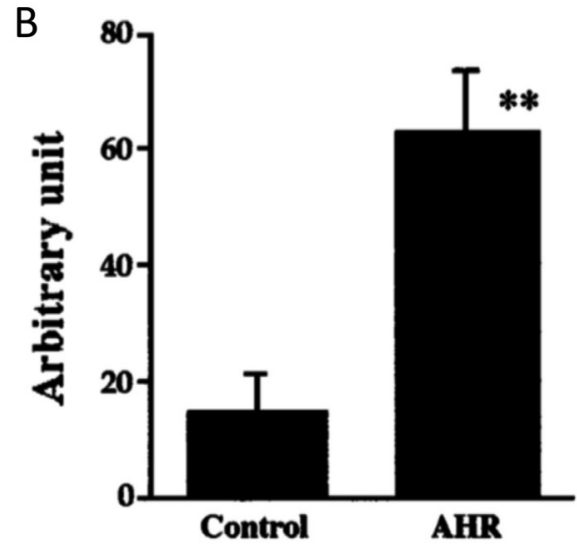

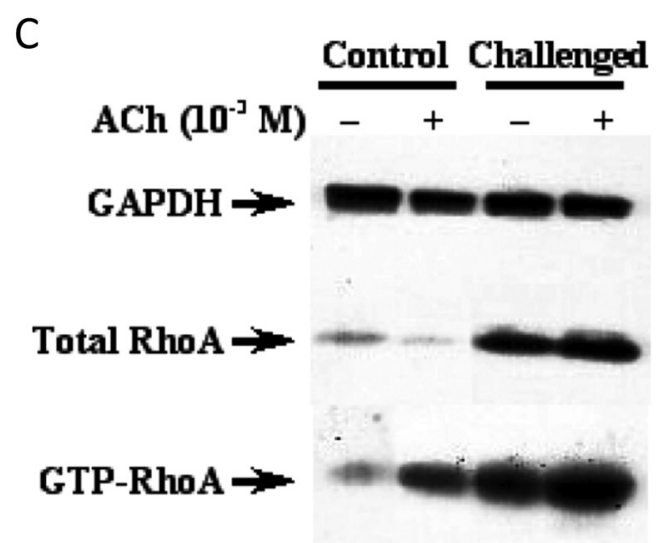

Fig. 4. Upregulation of RhoA expression and activity in BSM of airway hyperresponsive (AHR) animals. RhoA protein levels in intrapulmonary bronchi from control rats (Control) and antigen-induced AHR rats. (A, left) Representative immunoblot for RhoA expression. Lane 1, control; Lane 2, AHR; markers, protein molecular weight markers, and GAPDH. The data are summarized in (B). (C) Representative immunoblots showing RhoA activation in ACh-stimulated bronchi obtained from the Control and repeatedly antigen-challenged (Challenged) mice. Isolated bronchial tissues were incubated for $10 \mathrm{~min}$ in the absence $(-)$ or presence $(+)$ of $10^{-3}$ $\mathrm{M}$ ACh. Tissues were then rapidly lysed, and the GTP-bound active form of RhoA was pulled down with a GST-tagged Rho binding domain of rhotekin, and RhoA was visualized by Western blotting. $* * P<0.01$ vs. Control.

markedly increased in rat (Fig. 4A and B: Ref. (35)) and mouse (Fig. 4C: Ref. (29)) models of allergic asthma. In addition, when BSM was stimulated with contractile GPCR agonists such as ACh and endothelin-1, a higher expression of active form of RhoA was observed in the AHR animals (45). An augmented RhoA-mediated $\mathrm{Ca}^{2+}$ sensitization in smooth muscle contraction has been reported in experimental animal models of diseases such as hypertension $(31,35,46)$, and coronary $(29,47,48)$ and cerebral $(49-51)$ vasospasms. Thus, the signaling of RhoA and its downstream ROCKs are now considered as a therapeutic target of asthma (48-51), although the exact mechanism of up-regulation of RhoA is still unclear.

\section{Inflammatory Cytokines Upregulate RhoA Expression in BSMs}

Pro-inflammatory cytokines such as interleukin-1 $\beta$ (IL-1 $\beta$ ) and tumor necrosis factor- $\alpha$ (TNF- $\alpha$ ) may enhance the inflammatory response in asthma and may be linked to the disease severity. IL-1 $\beta$ and TNF- $\alpha$ have been shown to play a prominent role in developing airway responsiveness and airway inflammation in bron- 
chial asthma. Increased amounts of these cytokines have been detected in bronchoalveolar lavage (BAL) fluid $(52,53)$, and in the culture supernatants of alveolar macrophages from asthmatic patients $(54,55)$. Furthermore, it has been reported that inhaled TNF- $\alpha$ induced airway responsiveness to methacholine in humans (56). Therefore, we examined the effect of TNF- $\alpha$ on BSM contraction. Treatment of rat BSM with TNF- $\alpha$ resulted in a significant upward shift in the dose-response curve to $\mathrm{ACh}$, but not to high $\mathrm{K}^{+}$, compared with control tissues. The effect of TNF- $\alpha$ was completely blocked by pretreatment with the p42/44 MAPK inhibitor, U0126, or the protein synthesis inhibitor, cycloheximide, but not with the p38 MAPK inhibitor, SB203580. TNF- $\alpha$ treatment induced the phosphorylation of p42/44 MAPK and RhoA in the bronchial tissue. Furthermore, the TNF- $\alpha$-induced upregulation of RhoA was abolished by U0126 pretreatment (57).

In addition, cytokines derived from Th2 lymphocytes, including IL-4, IL-5, IL-9, IL-13 and IL-25, play a key role in the pathophysiology of asthma through the induction of eosinophilic airway inflammation. In the AHR rat model, total IgE in the serum, and IL-4, IL-6 and IL-13 in the BAL fluid were markedly and significantly increased compared with the control rats (58). An increased expression of IL-4 has been demonstrated in the BAL fluid after segmental allergen challenge to asthmatic patients (59). IL-4 promotes eosinophilic airway inflammation by increasing eotaxin expression and inhibiting eosinophil apoptosis (60). IL-4 induces mucus hypersecretion (61), which contributes to airway obstruction. Interestingly, IL-4 also acts on airway smooth muscles directly, and can cause hyperresponsiveness of airway smooth muscles (62). We thus examined the effect of IL-4 on the expression level of RhoA in human BSMCs (hBSMCs). Incubation of hBSMCs with IL-4 induced a distinct phosphorylation of signal transducer and activator of transcription 6 (STAT6), a major signal transducer activated by IL-4, indicating that IL-4 is capable of activating signal transduction in hBSMCs directly. IL-4 also induced a significant increase in the expression level of RhoA (63).

There is increasing evidence that IL-13 is also a central mediator of AHR induction (64-67). The human IL-13 gene is located on chromosome 5q in a region that has been linked to asthma $(68,69)$. An increased expression of IL-13 has been demonstrated in BAL cells obtained from patients with symptomatic asthma (70, 71). In addition, overexpression of IL-13 in mouse airway epithelial cells using the Clara cell $10-\mathrm{kD}$ protein gene promoter induced AHR to aerosolized methacholine (72). Intratracheal instillation of recombinant IL-13 to naive mice also evoked AHR to inhaled methacholine (73) and intravenously administered ACh (64). To elucidate the role of IL-13 in the induction of BSM hyperresponsiveness, the effects of IL-13 on both contractility and RhoA expression in BSM were investigated. In vivo treatment of airways with IL-13 by intranasal instillation induced a BSM hyperresponsiveness with RhoA upregulation in BSM of naive mice. Moreover, IL-13 induced RhoA upregulation. The IL-13-induced upregulation of RhoA was inhibited by leflunomide, a STAT6 inhibitor, in cultured hBSMCs. (74).

Glucocorticoids are the most effective therapy currently available for the treatment of allergic bronchial asthma. It is believed that in asthmatic patients glucocorticoids act primarily as anti-inflammatory agents, that is, inhibition of inflammatory cell recruitment and inhibition of release of pro-inflammatory mediators such as cytokines (75). We have reported that systemic treatment with glucocorticoid inhibited the BSM hypercontraction to the level of the control rats. Furthermore, glucocorticoids inhibited the RhoA upregulation and augmented ACh-induced activation of RhoA and phosphorylation of MLC (76). Many reports have demonstrated that glucocorticoids inhibited NF-kB activation in human airway smooth muscle (77-79). Hence, we investigated the effect of glucocorticoids on the IL-13 and TNF- $\alpha$-induced RhoA upregulation in hBSMCs. The TNF- $\alpha$ augmented promoter activity of rat RhoA was abolished by an IאB kinase (IKK) inhibitor. This observation suggests that the RhoA upregulation is induced by TNF- $\alpha$ only via NF- $\kappa B$, which was inhibited by glucocorticoids. However, the IL-13-augmented promoter activity of rat RhoA was partly inhibited by 
STAT6 inhibitor or IKK inhibitor, and abolished by both inhibitors together. These findings suggest that the IL-13-induced RhoA upregulation is mediated via activation of both STAT6 and NF- $\kappa$ B. The inhibitory effects of glucocorticoids on the IL-13-induced RhoA promoter activity and RhoA upregulation were induced by NFкB inhibition. Moreover, glucocorticoids may not be able to inhibit STAT6-induced transcription. (80). Taken together, glucocorticoids may inhibit NF-kB-induced transcription by interacting with the glucocorticoid receptors, resulting in inhibition of RhoA upregulation induced by IL-13 and TNF- $\alpha$.

\section{Involvement of MicroRNAs (miRNA) in RhoA Expression in Smooth Muscle Cells}

MicroRNAs (miRNAs), a class of small non-coding RNA, are associated with a variety of basic biological processes (81-84). Mature miRNAs regulate the expression of protein-coding genes by targeting their mRNA, leading to translational inhibition or RNA degradation (85). It has been demonstrated that cells transfected with miRNA generated contractility in vascular smooth muscle cells (86) and myometrial cells (87) by modulating gene expression.

The transcriptional/translational mechanism of RhoA is not well understood. However, it has been suggested that miR-133 negatively regulates RhoA expression in cardiomyocytes (88). RNA-hybrid analysis (http://bibiserv.techfak.uni-bielefeld.de/rnahybrid/) (89) of human and mouse RhoA mRNA revealed putative binding sites of miR-133a in the $3^{\prime}$-untranslated region (90). Based on this information, we have tested the hypothesis that downregulation of miR-133 induces RhoA upregulation in BSMs. We found that transfection of BSM cells with a miR-133a antagomir upregulated RhoA expression, whereas transfection with pre-miR133a downregulated it, suggesting that RhoA protein expression is negatively regulated by miR-133a in BSMs. We have also revealed that IL-13 treatment upregulated RhoA expression in hBSMCs $(74,91)$. IL-13, one of the major cytokines upregulated in the airways of patients with asthma, is important for the induction of AHR as described above. Thus, we speculated that the mechanism of RhoA upregulation is that IL-13 increases in the airways of asthmatic patients, inducing RhoA mRNA via STAT6 phosphorylation and RhoA translation via miR-133a downregulation in hBSMCs. These findings provide new insight into the roles of miR-133a in the suppression of excessive BSM contraction and suggest that the miR-133a/RhoA pathway is a putative therapeutic target for asthma.

\section{Involvement of $\mathrm{CPI}-17$ in Smooth Muscle Contraction}

PKC-potentiated inhibitory protein for heterotrimeric MLCP of $17 \mathrm{kDa}$ (CPI-17), which is activated by PKC and acts on an MLCP-specific target, was isolated from pig aorta smooth muscle extracts (92). CPI-17 expression is highly limited to smooth muscle tissues (93). When a contractile agonist binds to GPCR, PKC is activated via an increase in diacylglycerol (DG) and in turn phosphorylates CPI-17. Activated CPI-17 induces MLCP inhibition. CPI-17 is therefore important for the PKC-mediated $\mathrm{Ca}^{2+}$ sensitization in rabbit arterial smooth muscle $(94,95)$, human bladder smooth muscle (96), intestinal smooth muscle of rat (97) and mouse (98), human myometrium (99) and rat BSM (100-102).

In BSM of AHR animals, the mRNA and protein levels of CPI-17 were significantly increased compared with the controls (Fig. 5A and B, Ref. (103)). Upon contractile agonist stimulation of hyperresponsive BSM PKC/CPI-17 signaling activity increased by CPI-17 upregulation. Indeed, the phorbol 12,13-dibutyrate-mediated contraction was markedly augmented in BSM of AHR animals (104). ACh-induced phosphorylation of CPI-17 at Thr38 was significantly increased in BSM of AHR animals (Fig. 5C). Interestingly, pretreatment of AHR animals with Y-27632 or calphostin C, a PKC inhibitor, inhibited the ACh-induced phosphorylation of CPI-17 in bronchial tissues. Moreover, this pretreatment inhibited the ACh-induced phosphorylation of 
A
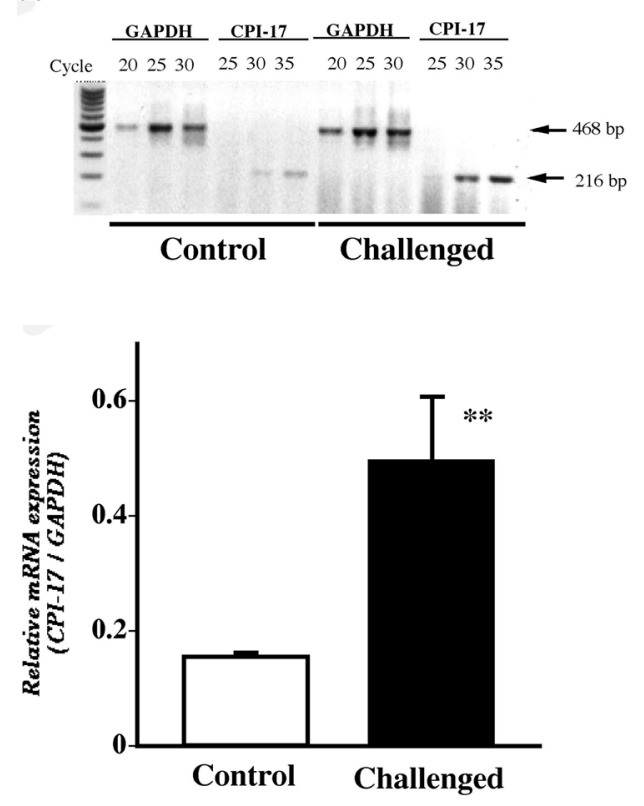

B
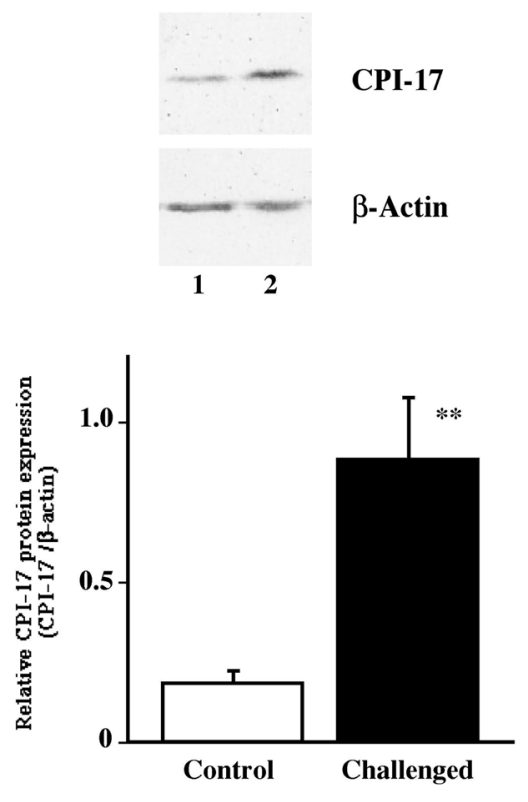

C

Control

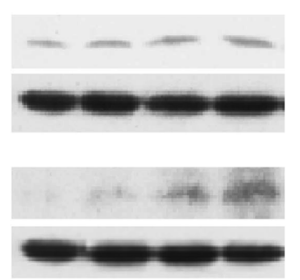

$\begin{array}{llll}\mathbf{0} & 5 & 4 & 3\end{array}$
Challenged

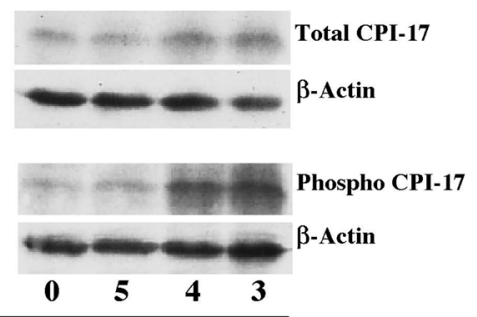

\begin{tabular}{lll}
5 & 3 \\
\hline
\end{tabular}

on $(-\log M)$

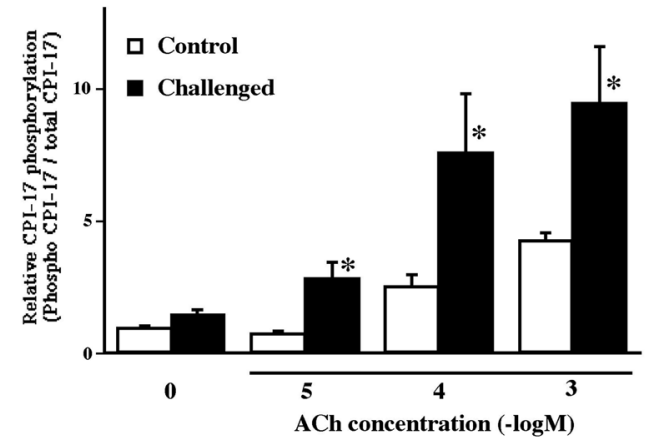

Fig. 5. Upregulation of CPI-17 expression and activity in BSM of airway hyperresponsive animals. CPI-17 mRNA expression levels in BSM from control rats (Control) and rats repeatedly challenged with antigen (Challenged). (A, top) Representative photographs of RT-PCR product bands of CPI-17 and GAPDH. PCR amplification was performed over 25 to 35 cycles $(C P I-17)$ or 20 to 30 cycles $(G A P D H)$. The bands were scanned, and the $C P I-17$ mRNA level is expressed as the density ratio of the $C P I-17$ to the GAPDH bands. The data are summarized at the bottom. (B) The CPI-17 protein levels in BSM from control (1) and rats repeatedly challenged with antigen (2 or Challenged). (Top) Representative photographs of CPI-17 and $\beta$-actin bands. The CPI-17 expression levels were calculated as the ratio of the intensities of CPI-17 and $\beta$-actin proteins, and are summarized at the bottom panel. (C) ACh-induced phosphorylation of CPI-17 in rat BSM from control rats and rats repeatedly challenged with antigen (Challenged). (Left) Representative immunoblots of phosphorylated CPI-17 (p[Thr38 CPI-17]) and total CPI-17. (Right) The phosphorylation levels of CPI-17 were calculated as the ratio of the intensities of phosphorylated CPI-17 (p[Thr38 CPI-17]) to total CPI-17 protein. Values are presented as the mean \pm S.E. of five experiments. ACh-induced phosphorylation was augmented in the repeated antigen-challenged group. $* P<0.05$ and $* * P<0.01$ vs. Control. 
MLC (100). The inhibitory effects of Y-27632 and calphostin C on agonist-induced phosphorylation of CPI17 have also been examined in rabbit femoral arterial smooth muscle (105). Treatment with glucocorticoids (prednisolone or beclomethasone) significantly inhibited the AHR, and markedly reduced both the protein and mRNA levels of CPI-17 in BSM. The ACh-induced activation of CPI-17 was also significantly inhibited by glucocorticoids. Glucocorticoids prevented the augmented ACh-induced MLC phosphorylation observed in rat AHR (106). Therefore, glucocorticoids may inhibit AHR through inhibition of CPI-17 overexpression and activation (106). To date, the transcription factors involved in CPI-17 expression in BSMs are unclear. Taken together, an increase in the PKC/CPI-17-mediated signaling is involved in the augmented BSM contraction in the mouse antigen-induced AHR. Thus, in addition to the RhoA-mediated signaling described above, the CPI17-mediated signaling is also a putative therapeutic target for the AHR in asthmatics. Furthermore, PKC/CPI17 and RhoA/ROCK/CPI-17 signaling may play key roles in the bronchoconstrictor-induced BSM contraction and MLC phosphorylation.

\section{Conclusion}

We propose that upregulation of RhoA and CPI-17 is associated with increased BSM contraction in asthma. Therefore, MLCP inhibitory signaling pathways via RhoA/ROCK, PKC/CPI-17 and their combination may be potential targets for new treatment of AHR in asthma. Furthermore, RhoA upregulation is induced in part by miR-133a downregulation, presumably resulting in contraction augmentation.

\section{(3) Vascular remodeling in pulmonary arterial hypertension}

\section{Introduction}

Pulmonary arterial hypertension $(\mathrm{PAH})$ is a serious and progressive disease characterized by pulmonary arterial hypertrophy and raised pulmonary vascular resistance, which results in diminished right-heart function due to increased right ventricular afterload. Estimates of the incidence of primary PAH range from 1 to 2 cases per million people in the general population. Before the development of recent therapeutic options, idiopathic pulmonary arterial hypertension was rapidly progressive and led to right heart failure and death. The research carried out between 1981 and 1985 indicated that the survival rates of PAH patient are 68\% at 1 year, $48 \%$ at 3 years and $34 \%$ at 5 years (107). In recent studies, PAH patients' estimated survival in the total cohort was $86.4 \%$ at 1 year, $72.9 \%$ at 3 years, and $65.4 \%$ at 5 years, between 2000 and 2012 (108). Pulmonary veno-occlusive disease (PVOD), one type of PAH, shows the progressive obstruction of small pulmonary veins and without therapeutic intervention few patients would be expected to survive more than two years (109). The mechanism of causing PAH is poorly understood although there are reports that portal hypertension, infection with the human immunodeficiency virus (HIV) and intake of appetite-suppressant drugs like fenfluramine cause PAH (110). In addition, heritable PAH patients have the mutations of the bone morphogenetic protein receptor type 2 gene (BMPR2), transforming growth factor- $\beta$ (TGF- $\beta$ ) type 1 receptor activin-like kinase-type 1 (ALK1) and a TGF- $\beta$ receptor complex subunit endoglin (ENG) (111-115).

As a treatment strategy, five different classes of drugs are now available-i.e., endothelin receptor antagonists, phosphodiesterase-5 inhibitors, soluble guanylate cyclase stimulators, prostacyclin analogues, and prostacyclin receptor agonists $(116,117)$. These drugs mostly improve distal vessel shrinkage on the initial stage of PAH. It is thus an urgent issue how to develop clinical methods targeting the process of vascular remodeling per se in order to cure serious PAH. 


\section{Arterial Remodeling of PAH}

The majority of PAH patients show the hypertensive vascular disease involving predominantly or exclusively muscular pulmonary arteries and arterioles associated with pulmonary artery medial hypertrophy and plexiform lesions. Normally, blood flows from right ventricle to lung via the pulmonary artery and fulfills gas exchange. However, PAH causes the thickening of pulmonary arteries/arterioles to narrow their diameters increasing the resistance of the pulmonary circulation. Therefore, to overcome this resistance increase, it is necessary to enhance the blood pressure gradient against the periphery of the pulmonary circulation, which often exceeds $25 \mathrm{mmHg}$ at rest, or $30 \mathrm{mmHg}$ during exercise $(118,119)$. The pathological background behind the blood pressure increase in PAH patients is vasoconstriction, vascular wall remodeling like intimal and medial thickening, and thrombus formation in situ (118). The plexiform lesion is a characteristic structure of the pulmonary arteriopathy in severe PAH. According to the consensus view, the plexiform lesion is a complex and disorganized pulmonary arterial proliferative lesion, which consists of a network or plexus of channels lined by endothelial cells and separated by core cells (120). However, it has not been determined whether the core cells are myofibroblasts, smooth muscle cells, or undifferentiated cells (121).

One major cause of PAH is vessel occlusion due to vascular endothelial remodeling. Normally, endothelial cells form a flat monolayer to construct the vessel surface called the endothelium. These cells generate constriction factors like endothelin and relaxation factors like nitric oxide (NO) $(122,123)$. Endothelial cells play important roles in keeping tissue homeostasis, prevent thrombus formation and protect cells residing inside of the vessel. In intimal and medial thickening, muscle-like cells increase exclusively (124). The expression of smooth muscle $\alpha$-actin ( $\alpha$-SMA) within neointimal layer has been a long-standing question for pathologists of what cell lineages contribute to the neointima (125). The most likely $\alpha$-SMA positive cells that may contribute to the pathological neointimal formation include, vascular smooth muscle cells undergoing dedifferentiation, myofibroblasts derived from migrating adventitial fibroblasts, and endothelial cells transitioning into mesenchymal cells (126). Expression of the endothelial von Willebrand antigen in plexiform lesions and microsatellite analyses used to infer individual plexiform lesions both suggest monoclonal expansions of endothelial cells (127). The endothelial-mesenchymal transition (EndoMT), which contributes to vascular fibrosis and angiogenesis and is actively involved in vascular remodeling, represents a biological process in which the endothelial cell progressively changes its phenotype into a mesenchymal or myofibroblastic one. During this process, endothelial cells dissociate from the monolayer of tightly cohesive cells at the abluminal surface of the vessel and migrate toward the inner tissue. In human pulmonary arterial hypertension, neointimal lesions contain cells that co-express endothelial clonal designator (CD) 31 or von Willebrand antigen and $\alpha$-SMA (128). These cells may participate in the endothelial phenotype transition that occurs with EndoMT where endothelial cells are assumed to have a smooth muscle or mesenchymal cell profile and contribute to neointima and plexiform formation.

During this remodeling process, vascular endothelial cells are exposed to a variety of pathological stimuli, for example, oxidative stress, mechanical stress such as sheer stress and elevated cytokine such as TGF- $\beta$, which is overactive in PAH (129-131). TGF- $\beta$ secretion augments cells transformation in numerous cell types. The canonical TGF- $\beta$ signaling pathway commences with binding of TGF- $\beta$ to a TGF- $\beta$ type 2 receptor, which subsequently heterodimerizes with a TGF- $\beta$ type 1 receptor (TGF- $\beta R 1$ ) to form an active TGF- $\beta R 1$ complex. The activated TGF- $\beta$ Rl complex phosphorylates the transcription factors SMAD-2 and SMAD-3, which in turn promotes collagen synthesis $(132,133)$. The phosphorylation of SMAD-2, a cytoplasmic signaling protein downstream from the TGF- $\beta$ receptor 1 (activin-like kinase-5, or ALK5), is increased in plexiform lesions of patients with PAH (134). There are several types of TGF isotype, for example TGF- $\beta 1$, TGF- $\beta 2$ and TGF- $\beta 3$, 
and they have important roles in angiogenesis (135-137). These cytokines are known to cause the phenotypic transformation of endothelial cells to mesenchymal cells, in other words, endothelial remodeling. Transdifferentiation of epithelial cells into mesenchymal cells so called epithelial mesenchymal transition (EMT) is known to be crucial for carcinogenesis and cancer cell migration $(138,139)$. Recently several groups have demonstrated that PAH is a disease of excess proliferation and impaired apoptosis similar to neoplasia. This similarity raises the possibility that antiproliferative and/or oncological drugs may exert therapeutic effects in PAH, too (140). Loss-of-function mutations in the BMPR-2, a member of the TGF- $\beta$ superfamily, underlie the majority $(>80 \%)$ of the cases of heritable PAH, identifying an important role for TGF- $\beta$ signaling in the development of PAH (141).

\section{Contribution of TRP Channels on Pulmonary Arterial Remodeling}

Pulmonary arterial remodeling is induced by multiple physical and chemical stimuli. Chronic hypoxic exposure induces changes in the structure of pulmonary arteries, as well as in the biochemical and functional phenotypes of each of the vascular cell types (142). It is known for long that cytosolic $\mathrm{Ca}^{2+}$ level and membrane potential are crucial factors to initiate the signal transduction cascades, leading to diverse vascular functions (143). Amongst various kinds of ion channels that regulate ion homeostasis, transient receptor potential (TRP) channels emerge as the important mediators for a diverse range of vascular signaling. The characteristics of TRP channels, including subunit heteromultimerization, diverse ion selectivity, and multiple modes of activation, permit their multiple functional roles in vasculatures $(144,145)$. Evidence demonstrates that TRP channels participate in physiological and pathophysiological processes of vascular system including pulmonary circulation $(146,147)$.

TRP channels are a unique group of ion channels that serve as cellular sensors for a wide spectrum of physical and chemical stimuli. There are 28 distinct members of the TRP channels superfamily and 20 members of it express in mammalian organs. The discovery of the TRP channels superfamily stems is due to the study of Drosophila phototransduction $(148,149)$. All member of the TRP channel superfamily are expressed as polypeptides of 553-2,022 amino acids and have the six-transmembrane topology. Improvement of X-ray diffraction and cryo-electron microscopy revealed the detail of the TRP channel's structure (150, 151). Depending on the structure, TRP channels are categorized for 6 groups; ankyrin (TRPA), canonical (TRPC), melastatin (TRPM), polycystin (TRPP), vanilloid (TRPV) and mucolipin (TRPML).

In pulmonary arterial smooth muscle cells (PASMC), accumulating data indicates that elevated basal $\mathrm{Ca}^{2+}$ concentration occurs primarily via upregulation of TRPC proteins, which comprise a subfamily of receptor-/ store-operated $\mathrm{Ca}^{2+}$-permeable nonselective cation channels, and this is required for PASMC growth and migration (152). TRPC1 channel contribute to vascular remodeling in PAH induced by hypoxia (153). TRPV1 and TRPV4 are expressed in PASMC and implicated in the remodeling of pulmonary artery $(154,155)$. TRPM7 is a stretch- and swelling-activated channel, which is known to promote tissue remodeling in the cardiovascular system, and critically contributes to vascular stress fiber formation (156). It has been reported that endothelial proliferation/transformation of vascular endothelial cells are regulated by TRPM7 activity through activation of the extracellular signal-regulated kinase (ERK)-mediated pathway (157). Furthermore, $\mathrm{Ca}^{2+}$ influx into the intracellular space via TRPM7 is shown to enhance endothelial cell migration in response to lipopolysaccharide (LPS) (158).

We investigated how TRPM7 affect EndoMT in human endothelial cells. To regulate TRPM7 channel activity, we employed a selective TRPM7 blocker, FTY720, a drug used to treat multiple sclerosis $(159,160)$. This agent is chemo-synthesized from myriocin, an ingredient of Isaria sinclairii. Isaria sinclairii is native to 
Asia, and is classified as an entomopathogenic fungus. It is the imperfect stage of Cordyceps sinclairii (Clavicipitaceae) and is closely related to Cordyceps sinensis Sacc., whose Chinese name, Dong Chong Xia Cao, means "winter worm, summer grass"; this species was reclassified recently to Ophiocordyceps sinensis (161). The Cordyceps sinensis has been shown to possess various therapeutic benefits for fibrotic disorders $(162,163)$.

We evaluated the effects of FTY720, Cordyceps sinesis, TRPM7-siRNA, FYN-siRNA, and FYN mutants on TGF- $\beta 2$ induced EndoMT and stress fiber formation in HUVECs respectively by immunocytochemical, real-time RT-PCR and western blot analyses. Immunocytochemistry indicated that the TRPM7 antagonist FTY720 and Cordyceps sinensis suppress TGF- $\beta 2$-induced stress fiber formation. Immunoblot analysis of mesenchymal markers: N-cadherin and $\alpha$-SMA and endothelial Markers: VE-cadherin and CD31 suggested that FTY-720 and TRPM7-siRNA effectively suppress TGF- $\beta 2$ induced EndoMT.

The MCT rat model is a frequently investigated model of PAH, since it offers technical simplicity, reproducibility, and low cost compared with the other models of PAH. MCT is a toxic pyrrolizidine alkaloid present in the plant Crotalaria spectabilis. Ingestion of MCT results in the progressive development of PAH in various animal species and was first described after repeated oral ingestion in laboratory rats more than 40 years ago (164). We observed that treatment of Cordyceps sinensis on MCT-PAH rats ameliorated the development of pulmonary artery thickening, cardiac fibrosis and right ventricle hypertrophy. Moreover, the expression of TRPM7 was clearly upregulated at endothelial remodeling area and plexiform lesion in the lung tissue from PAH patients. These findings can most simplistically be interpreted that TRPM7 at least in part contributes to the EndoMT process of vascular endothelial remodeling, and could thus become a novel target of anti-remodeling therapy for many cardiovascular diseases. This new information will serve as a groundbreaking strategy to treat fibrotic disorders in the cardiovascular system.

Not only limited to TRPM7, it is likely that multiple TRP channels avidly function in the process of pulmonary vascular remodeling, many of which may be essential to cause PAH. Hence, future therapeutic interventions should target multiple signaling pathways to ameliorate the aberrant vascular remodeling that occurs in PAH.

\section{Presentation at a Symposium}

This review is based on the symposium held at the 58th annual meeting of the Japan Society of Smooth Muscle Research in Sendai, Japan.

\section{Conflict of Interest}

The authors declare no conflicts of interest in this study.

\section{References}

1. Chen GY, Nuñez G. Sterile inflammation: sensing and reacting to damage. Nat Rev Immunol. 2010; 10(12): 826-37 http://www.ncbi.nlm.nih.gov/pubmed/21088683. [Medline] [CrossRef]

2. Davis BK, Wen H, Ting JP. The inflammasome NLRs in immunity, inflammation, and associated diseases. Annu Rev Immunol. 2011; 29: 707-35 http://www.ncbi.nlm.nih.gov/pubmed/21219188. [Medline] [CrossRef]

3. Strowig T, Henao-Mejia J, Elinav E, Flavell R. Inflammasomes in health and disease. Nature. 2012; 
481(7381): 278-86 http://www.ncbi.nlm.nih.gov/pubmed/22258606. [Medline] [CrossRef]

4. Tedgui A, Mallat Z. Cytokines in atherosclerosis: pathogenic and regulatory pathways. Physiol Rev. 2006; 86(2): 515-81 http://www.ncbi.nlm.nih.gov/pubmed/16601268. [Medline] [CrossRef]

5. Kirii H, Niwa T, Yamada Y, Wada H, Saito K, Iwakura Y, Asano M, Moriwaki H, Seishima M. Lack of interleukin-1beta decreases the severity of atherosclerosis in ApoE-deficient mice. Arterioscler Thromb Vasc Biol. 2003; 23(4): 656-60 http://www.ncbi.nlm.nih.gov/pubmed/12615675. [Medline] [CrossRef]

6. Shimizu K, Mitchell RN, Libby P. Inflammation and cellular immune responses in abdominal aortic aneurysms. Arterioscler Thromb Vasc Biol. 2006; 26(5): 987-94 http://www.ncbi.nlm.nih.gov/ pubmed/16497993. [Medline] [CrossRef]

7. Daugherty A, Cassis LA. Mouse models of abdominal aortic aneurysms. Arterioscler Thromb Vasc Biol. 2004; 24(3): 429-34 http://www.ncbi.nlm.nih.gov/pubmed/14739119. [Medline] [CrossRef]

8. Yoshimura K, Aoki H, Ikeda Y, Fujii K, Akiyama N, Furutani A, Hoshii Y, Tanaka N, Ricci R, Ishihara T, Esato K, Hamano K, Matsuzaki M. Regression of abdominal aortic aneurysm by inhibition of cJun N-terminal kinase. Nat Med. 2005; 11(12): 1330-8 http://www.ncbi.nlm.nih.gov/pubmed/16311603. [Medline] [CrossRef]

9. Zhang SH, Reddick RL, Piedrahita JA, Maeda N. Spontaneous hypercholesterolemia and arterial lesions in mice lacking apolipoprotein E. Science. 1992; 258(5081): 468-71 http://www.ncbi.nlm.nih.gov/ pubmed/1411543. [Medline] [CrossRef]

10. Boström K. Proinflammatory vascular calcification. Circ Res. 2005; 96(12): 1219-20 http://www.ncbi. nlm.nih.gov/pubmed/15976320. [Medline] [CrossRef]

11. Rajamäki K, Lappalainen J, Oörni K, Välimäki E, Matikainen S, Kovanen PT, Eklund KK. Cholesterol crystals activate the NLRP3 inflammasome in human macrophages: a novel link between cholesterol metabolism and inflammation. PLoS One. 2010; 5(7): e11765 http://www.ncbi.nlm.nih.gov/ pubmed/20668705. [Medline] [CrossRef]

12. Duewell P, Kono H, Rayner KJ, Sirois CM, Vladimer G, Bauernfeind FG, Abela GS, Franchi L, Nuñez G, Schnurr M, Espevik T, Lien E, Fitzgerald KA, Rock KL, Moore KJ, Wright SD, Hornung V, Latz E. NLRP3 inflammasomes are required for atherogenesis and activated by cholesterol crystals. Nature. 2010; 464(7293): 1357-61 http://www.ncbi.nlm.nih.gov/pubmed/20428172. [Medline] [CrossRef]

13. Usui F, Shirasuna K, Kimura H, Tatsumi K, Kawashima A, Karasawa T, Hida S, Sagara J, Taniguchi S, Takahashi M. Critical role of caspase-1 in vascular inflammation and development of atherosclerosis in Western diet-fed apolipoprotein E-deficient mice. Biochem Biophys Res Commun. 2012; 425(2): 162-8 http://www.ncbi.nlm.nih.gov/pubmed/22819845. [Medline] [CrossRef]

14. Daugherty A, Manning MW, Cassis LA. Angiotensin II promotes atherosclerotic lesions and aneurysms in apolipoprotein E-deficient mice. J Clin Invest. 2000; 105(11): 1605-12 http://www.ncbi.nlm.nih.gov/ pubmed/10841519. [Medline] [CrossRef]

15. Nakahira K, Haspel JA, Rathinam VA, Lee SJ, Dolinay T, Lam HC, Englert JA, Rabinovitch M, Cernadas M, Kim HP, Fitzgerald KA, Ryter SW, Choi AM. Autophagy proteins regulate innate immune responses by inhibiting the release of mitochondrial DNA mediated by the NALP3 inflammasome. Nat Immunol. 2011; 12(3): 222-30 http://www.ncbi.nlm.nih.gov/pubmed/21151103. [Medline] [CrossRef]

16. Shimada K, Crother TR, Karlin J, Dagvadorj J, Chiba N, Chen S, Ramanujan VK, Wolf AJ, Vergnes L, Ojcius DM, Rentsendorj A, Vargas M, Guerrero C, Wang Y, Fitzgerald KA, Underhill DM, Town T, Arditi M. Oxidized mitochondrial DNA activates the NLRP3 inflammasome during apoptosis. Immunity. 2012; 36(3): 401-14 http://www.ncbi.nlm.nih.gov/pubmed/22342844. [Medline] [CrossRef]

17. Zhou R, Yazdi AS, Menu P, Tschopp J. A role for mitochondria in NLRP3 inflammasome activation. Nature. 2011; 469(7329): 221-5 http://www.ncbi.nlm.nih.gov/pubmed/21124315. [Medline] [CrossRef]

18. Dostert C, Pétrilli V, Van Bruggen R, Steele C, Mossman BT, Tschopp J. Innate immune activation through Nalp3 inflammasome sensing of asbestos and silica. Science. 2008; 320(5876): 674-7 http:// www.ncbi.nlm.nih.gov/pubmed/18403674. [Medline] [CrossRef] 
19. Mariathasan S, Weiss DS, Newton K, McBride J, O’Rourke K, Roose-Girma M, Lee WP, Weinrauch Y, Monack DM, Dixit VM. Cryopyrin activates the inflammasome in response to toxins and ATP. Nature. 2006; 440(7081): 228-32 http://www.ncbi.nlm.nih.gov/pubmed/16407890. [Medline] [CrossRef]

20. Usui F, Shirasuna K, Kimura H, Tatsumi K, Kawashima A, Karasawa T, Yoshimura K, Aoki H, Tsutsui H, Noda T, Sagara J, Taniguchi S, Takahashi M. Inflammasome activation by mitochondrial oxidative stress in macrophages leads to the development of angiotensin II-induced aortic aneurysm. Arterioscler Thromb Vasc Biol. 2015; 35(1): 127-36 http://www.ncbi.nlm.nih.gov/pubmed/25378412. [Medline] [CrossRef]

21. Busse WW, Lemanske RF Jr. Asthma. N Engl J Med. 2001; 344(5): 350-62 http://www.ncbi.nlm.nih. gov/pubmed/11172168. [Medline] [CrossRef]

22. Girodet PO, Ozier A, Trian T, Begueret H, Ousova O, Vernejoux JM, Chanez P, Marthan R, Berger P, Tunon de Lara JM. Mast cell adhesion to bronchial smooth muscle in asthma specifically depends on CD51 and CD44 variant 6. Allergy. 2010; 65(8): 1004-12 http://www.ncbi.nlm.nih.gov/pubmed/20121756. [Medline] [CrossRef]

23. Denis D, Fayon MJ, Berger P, Molimard M, De Lara MT, Roux E, Marthan R. Prolonged moderate hyperoxia induces hyperresponsiveness and airway inflammation in newborn rats. Pediatr Res. 2001; 50(4): 515-9 http://www.ncbi.nlm.nih.gov/pubmed/11568296. [Medline] [CrossRef]

24. Cockcroft DW, Killian DN, Mellon JJ, Hargreave FE. Bronchial reactivity to inhaled histamine: a method and clinical survey. Clin Allergy. 1977; 7(3): 235-43 http://www.ncbi.nlm.nih.gov/pubmed/908121. [Medline] [CrossRef]

25. Juniper EF, Frith PA, Hargreave FE. Airway responsiveness to histamine and methacholine: relationship to minimum treatment to control symptoms of asthma. Thorax. 1981; 36(8): 575-9 http://www. ncbi.nlm.nih.gov/pubmed/7031972. [Medline] [CrossRef]

26. Peat JK, Woolcock AJ, Cullen K. Rate of decline of lung function in subjects with asthma. Eur J Respir Dis. 1987; 70(3): 171-9 http://www.ncbi.nlm.nih.gov/pubmed/3569449. [Medline]

27. James AL, Paré PD, Hogg JC. The mechanics of airway narrowing in asthma. Am Rev Respir Dis. 1989; 139(1): 242-6 http://www.ncbi.nlm.nih.gov/pubmed/2912345. [Medline] [CrossRef]

28. Misawa M, Chiba Y. Repeated antigenic challenge-induced airway hyperresponsiveness and airway inflammation in actively sensitized rats. Jpn J Pharmacol. 1993; 61(1): 41-50 http://www.ncbi.nlm.nih. gov/pubmed/8382324. [Medline] [CrossRef]

29. Chiba Y, Ueno A, Shinozaki K, Takeyama H, Nakazawa S, Sakai H, Misawa M. Involvement of RhoAmediated $\mathrm{Ca}^{2+}$ sensitization in antigen-induced bronchial smooth muscle hyperresponsiveness in mice. Respir Res. 2005; 6: 4 http://www.ncbi.nlm.nih.gov/pubmed/15638941. [Medline] [CrossRef]

30. Kato Y, Manabe T, Tanaka Y, Mochizuki H. Effect of an orally active Th1/Th2 balance modulator, M50367, on IgE production, eosinophilia, and airway hyperresponsiveness in mice. J Immunol. 1999; 162(12): 7470-9 https://www.jimmunol.org/content/162/12/7470. [Medline]

31. Seow CY, Schellenberg RR, Paré PD. Structural and functional changes in the airway smooth muscle of asthmatic subjects. Am J Respir Crit Care Med. 1998; $158(5$ Pt 3): S179-86 http://www.ncbi.nlm.nih. gov/pubmed/9817743. [Medline] [CrossRef]

32. Chiba Y, Misawa M. Characteristics of muscarinic cholinoceptors in airways of antigen-induced airway hyperresponsive rats. Comp Biochem Physiol C Pharmacol Toxicol Endocrinol. 1995; 111(3): 351-7 http://www.ncbi.nlm.nih.gov/pubmed/8564779. [Medline] [CrossRef]

33. Chiba Y, Sakai H, Suenaga H, Kamata K, Misawa M. Enhanced $\mathrm{Ca}^{2+}$ sensitization of the bronchial smooth muscle contraction in antigen-induced airway hyperresponsive rats. Res Commun Mol Pathol Pharmacol. 1999; 106(1-2): 77-85 http://www.ncbi.nlm.nih.gov/pubmed/11127810. [Medline]

34. Chiba Y, Misawa M. Alteration in $\mathrm{Ca}^{2+}$ availability involved in antigen-induced airway hyperresponsiveness in rats. Eur J Pharmacol. 1995; 278(1): 79-82 http://www.ncbi.nlm.nih.gov/pubmed/7664816. [Medline] [CrossRef] 
35. Chiba Y, Takada Y, Miyamoto S, MitsuiSaito M, Karaki H, Misawa M. Augmented acetylcholineinduced, Rho-mediated $\mathrm{Ca}^{2+}$ sensitization of bronchial smooth muscle contraction in antigen-induced airway hyperresponsive rats. Br J Pharmacol. 1999; 127(3): 597-600 http://www.ncbi.nlm.nih.gov/ pubmed/10401547. [Medline] [CrossRef]

36. Somlyo AP, Somlyo AV. Signal transduction and regulation in smooth muscle. Nature. 1994; 372(6503): 231-6 http://www.ncbi.nlm.nih.gov/pubmed/7969467. [Medline] [CrossRef]

37. Hartshorne DJ, Ito M, Erdödi F. Role of protein phosphatase type 1 in contractile functions: myosin phosphatase. J Biol Chem. 2004; 279(36): 37211-4 http://www.ncbi.nlm.nih.gov/pubmed/15136561. [Medline] [CrossRef]

38. Somlyo AP, Somlyo AV. $\mathrm{Ca}^{2+}$ sensitivity of smooth muscle and nonmuscle myosin II: modulated by $\mathrm{G}$ proteins, kinases, and myosin phosphatase. Physiol Rev. 2003; 83(4): 1325-58 http://www.ncbi.nlm.nih. gov/pubmed/14506307. [Medline] [CrossRef]

39. Noda M, Yasuda-Fukazawa C, Moriishi K, Kato T, Okuda T, Kurokawa K, Takuwa Y. Involvement of rho in GTP gamma S-induced enhancement of phosphorylation of $20 \mathrm{kDa}$ myosin light chain in vascular smooth muscle cells: inhibition of phosphatase activity. FEBS Lett. 1995; 367(3): 246-50 http://www. ncbi.nlm.nih.gov/pubmed/7607316. [Medline] [CrossRef]

40. Matsui T, Amano M, Yamamoto T, Chihara K, Nakafuku M, Ito M, Nakano T, Okawa K, Iwamatsu A, Kaibuchi K. Rho-associated kinase, a novel serine/threonine kinase, as a putative target for small GTP binding protein Rho. EMBO J. 1996; 15(9): 2208-16 http://www.ncbi.nlm.nih.gov/pubmed/8641286. [Medline] [CrossRef]

41. Ishizaki T, Naito M, Fujisawa K, Maekawa M, Watanabe N, Saito Y, Narumiya S. p160ROCK, a Rhoassociated coiled-coil forming protein kinase, works downstream of Rho and induces focal adhesions. FEBS Lett. 1997; 404(2-3): 118-24 http://www.ncbi.nlm.nih.gov/pubmed/9119047. [Medline] [CrossRef]

42. Leung T, Manser E, Tan L, Lim L. A novel serine/threonine kinase binding the Ras-related RhoA GTPase which translocates the kinase to peripheral membranes. J Biol Chem. 1995; 270(49): 29051-4 http://www.ncbi.nlm.nih.gov/pubmed/7493923. [Medline] [CrossRef]

43. Murányi A, Derkach D, Erdodi F, Kiss A, Ito M, Hartshorne DJ. Phosphorylation of Thr695 and Thr850 on the myosin phosphatase target subunit: inhibitory effects and occurrence in A7r5 cells. FEBS Lett. 2005; 579(29): 6611-5 http://www.ncbi.nlm.nih.gov/pubmed/16297917. [Medline] [CrossRef]

44. Chiba Y, Takeyama H, Sakai H, Misawa M. Effects of Y-27632 on acetylcholine-induced contraction of intact and permeabilized intrapulmonary bronchial smooth muscles in rats. Eur J Pharmacol. 2001; 427(1): 77-82 http://www.ncbi.nlm.nih.gov/pubmed/11553366. [Medline] [CrossRef]

45. Chiba Y, Sakai H, Misawa M. Augmented acetylcholine-induced translocation of RhoA in bronchial smooth muscle from antigen-induced airway hyperresponsive rats. Br J Pharmacol. 2001; 133(6): 88690 http://www.ncbi.nlm.nih.gov/pubmed/11454662. [Medline] [CrossRef]

46. Martin JG, Duguet A, Eidelman DH. The contribution of airway smooth muscle to airway narrowing and airway hyperresponsiveness in disease. Eur Respir J. 2000; 16(2): 349-54 http://www.ncbi.nlm.nih. gov/pubmed/10968513. [Medline] [CrossRef]

47. Schembri F, Sridhar S, Perdomo C, Gustafson AM, Zhang X, Ergun A, Lu J, Liu G, Zhang X, Bowers J, Vaziri C, Ott K, Sensinger K, Collins JJ, Brody JS, Getts R, Lenburg ME, Spira A. MicroRNAs as modulators of smoking-induced gene expression changes in human airway epithelium. Proc Natl Acad Sci USA. 2009; 106(7): 2319-24 http://www.ncbi.nlm.nih.gov/pubmed/19168627. [Medline] [CrossRef]

48. Gosens R, Schaafsma D, Nelemans SA, Halayko AJ. Rho-kinase as a drug target for the treatment of airway hyperrespon-siveness in asthma. Mini Rev Med Chem. 2006; 6(3): 339-48 http://www.ncbi.nlm. nih.gov/pubmed/16515473. [Medline] [CrossRef]

49. Schaafsma D, Gosens R, Zaagsma J, Halayko AJ, Meurs H. Rho kinase inhibitors: a novel therapeutical intervention in asthma? Eur J Pharmacol. 2008; 585(2-3): 398-406 http://www.ncbi.nlm.nih.gov/ 
pubmed/18410919. [Medline] [CrossRef]

50. Schaafsma D, Roscioni SS, Meurs H, Schmidt M. Monomeric G-proteins as signal transducers in airway physiology and pathophysiology. Cell Signal. 2008; 20(10): 1705-14 http://www.ncbi.nlm.nih.gov/ pubmed/18538541. [Medline] [CrossRef]

51. Kume H. RhoA/Rho-kinase as a therapeutic target in asthma. Curr Med Chem. 2008; 15(27): 2876-85 http://www.ncbi.nlm.nih.gov/pubmed/18991642. [Medline] [CrossRef]

52. Broide DH, Lotz M, Cuomo AJ, Coburn DA, Federman EC, Wasserman SI. Cytokines in symptomatic asthma airways. J Allergy Clin Immunol. 1992; 89(5): 958-67 https://www.ncbi.nlm.nih.gov/ pubmed/1374772. [Medline] [CrossRef]

53. Ying S, Robinson DS, Varney V, Meng Q, Tsicopoulos A, Moqbel R, Durham SR, Kay AB, Hamid Q. TNF alpha mRNA expression in allergic inflammation. Clin Exp Allergy. 1991; 21(6): 745-50 https:// www.ncbi.nlm.nih.gov/pubmed/1777835. [Medline] [CrossRef]

54. Gosset P, Tsicopoulos A, Wallaert B, Vannimenus C, Joseph M, Tonnel AB, Capron A. Increased secretion of tumor necrosis factor alpha and interleukin- 6 by alveolar macrophages consecutive to the development of the late asthmatic reaction. J Allergy Clin Immunol. 1991; 88(4): 561-71 https://www. ncbi.nlm.nih.gov/pubmed/1918723. [Medline] [CrossRef]

55. Azevedo I, de Blic J, Dumarey CH, Scheinmann P, Vargaftig BB, Bachelet M. Increased spontaneous release of tumour necrosis factor-alpha by alveolar macrophages from wheezy infants. Eur Respir J. 1997; 10(8): 1767-73 https://www.ncbi.nlm.nih.gov/pubmed/9272917. [Medline] [CrossRef]

56. Thomas PS, Yates DH, Barnes PJ. Tumor necrosis factor-alpha increases airway responsiveness and sputum neutrophilia in normal human subjects. Am J Respir Crit Care Med. 1995; 152(1): $76-80$ https:// www.ncbi.nlm.nih.gov/pubmed/7599866. [Medline] [CrossRef]

57. Sakai H, Otogoto S, Chiba Y, Abe K, Misawa M. Involvement of p42/44 MAPK and RhoA protein in augmentation of ACh-induced bronchial smooth muscle contraction by TNF-alpha in rats. J Appl Physiol 1985. 2004; 97(6): 2154-9 https://www.ncbi.nlm.nih.gov/pubmed/15322069. [Medline] [CrossRef]

58. Chiba Y, Arima J, Sakai H, Misawa M. Lovastatin inhibits bronchial hyperresponsiveness by reducing RhoA signaling in rat allergic asthma. Am J Physiol Lung Cell Mol Physiol. 2008; 294(4): L705-13 http://www.ncbi.nlm.nih.gov/pubmed/18296496. [Medline] [CrossRef]

59. Batra V, Musani AI, Hastie AT, Khurana S, Carpenter KA, Zangrilli JG, Peters SP. Bronchoalveolar lavage fluid concentrations of transforming growth factor (TGF)-beta1, TGF-beta2, interleukin (IL)-4 and IL-13 after segmental allergen challenge and their effects on alpha-smooth muscle actin and collagen III synthesis by primary human lung fibroblasts. Clin Exp Allergy. 2004; 34(3): 437-44 http://www. ncbi.nlm.nih.gov/pubmed/15005738. [Medline] [CrossRef]

60. Steinke JW, Borish L. Th2 cytokines and asthma. Interleukin-4: its role in the pathogenesis of asthma, and targeting it for asthma treatment with interleukin-4 receptor antagonists. Respir Res. 2001; 2(2): 66-70 http://www.ncbi.nlm.nih.gov/pubmed/11686867. [Medline] [CrossRef]

61. Dabbagh K, Takeyama K, Lee HM, Ueki IF, Lausier JA, Nadel JA. IL-4 induces mucin gene expression and goblet cell metaplasia in vitro and in vivo. J Immunol. 1999; 162(10): 6233-7 http://www.ncbi.nlm. nih.gov/pubmed/10229869. [Medline]

62. Bryborn M, Adner M, Cardell LO. Interleukin-4 increases murine airway response to kinins, via upregulation of bradykinin B1-receptors and altered signalling along mitogen-activated protein kinase pathways. Clin Exp Allergy. 2004; 34(8): 1291-8 http://www.ncbi.nlm.nih.gov/pubmed/15298572. [Medline] [CrossRef]

63. Chiba Y, Sakai H, Wachi H, Sugitani H, Seyama Y, Misawa M. Upregulation of rhoA mRNA in bronchial smooth muscle of antigen-induced airway hyperresponsive rats. J Smooth Muscle Res. 2003; 39(6): 221-8 http://www.ncbi.nlm.nih.gov/pubmed/15048014. [Medline] [CrossRef]

64. Wills-Karp M, Luyimbazi J, Xu X, Schofield B, Neben TY, Karp CL, Donaldson DD. Interleukin-13: central mediator of allergic asthma. Science. 1998; 282(5397): 2258-61 http://www.ncbi.nlm.nih.gov/ 
pubmed/9856949. [Medline] [CrossRef]

65. Grünig G, Warnock M, Wakil AE, Venkayya R, Brombacher F, Rennick DM, Sheppard D, Mohrs M, Donaldson DD, Locksley RM, Corry DB. Requirement for IL-13 independently of IL-4 in experimental asthma. Science. 1998; 282(5397): 2261-3 http://www.ncbi.nlm.nih.gov/pubmed/9856950. [Medline] [CrossRef]

66. Walter DM, McIntire JJ, Berry G, McKenzie AN, Donaldson DD, DeKruyff RH, Umetsu DT. Critical role for IL-13 in the development of allergen-induced airway hyperreactivity. J Immunol. 2001; 167(8): 4668-75 http://www.ncbi.nlm.nih.gov/pubmed/11591797. [Medline] [CrossRef]

67. Zhu Z, Zheng T, Homer RJ, Kim YK, Chen NY, Cohn L, Hamid Q, Elias JA. Acidic mammalian chitinase in asthmatic Th2 inflammation and IL-13 pathway activation. Science. 2004; 304(5677): 1678-82 http://www.ncbi.nlm.nih.gov/pubmed/15192232. [Medline] [CrossRef]

68. Postma DS, Bleecker ER, Amelung PJ, Holroyd KJ, Xu J, Panhuysen CI, Meyers DA, Levitt RC. Genetic susceptibility to asthma--bronchial hyperresponsiveness coinherited with a major gene for atopy. $\mathrm{N}$ Engl J Med. 1995; 333(14): 894-900 http://www.ncbi.nlm.nih.gov/pubmed/7666875. [Medline] [CrossRef]

69. Palmer LJ, Daniels SE, Rye PJ, Gibson NA, Tay GK, Cookson WO, Goldblatt J, Burton PR, LeSöuef PN. Linkage of chromosome $5 \mathrm{q}$ and $11 \mathrm{q}$ gene markers to asthma-associated quantitative traits in Australian children. Am J Respir Crit Care Med. 1998; 158(6): 1825-30 http://www.ncbi.nlm.nih.gov/ pubmed/9847274. [Medline] [CrossRef]

70. Bodey KJ, Semper AE, Redington AE, Madden J, Teran LM, Holgate ST, Frew AJ. Cytokine profiles of BAL T cells and T-cell clones obtained from human asthmatic airways after local allergen challenge. Allergy. 1999; 54(10): 1083-93 http://www.ncbi.nlm.nih.gov/pubmed/10536887. [Medline] [CrossRef]

71. Prieto J, Lensmar C, Roquet A, van der Ploeg I, Gigliotti D, Eklund A, Grunewald J. Increased interleukin-13 mRNA expression in bronchoalveolar lavage cells of atopic patients with mild asthma after repeated low-dose allergen provocations. Respir Med. 2000; 94(8): 806-14 http://www.ncbi.nlm.nih. gov/pubmed/10955758. [Medline] [CrossRef]

72. Zhu Z, Homer RJ, Wang Z, Chen Q, Geba GP, Wang J, Zhang Y, Elias JA. Pulmonary expression of interleukin-13 causes inflammation, mucus hypersecretion, subepithelial fibrosis, physiologic abnormalities, and eotaxin production. J Clin Invest. 1999; 103(6): 779-88 http://www.ncbi.nlm.nih.gov/ pubmed/10079098. [Medline] [CrossRef]

73. Yang M, Hogan SP, Henry PJ, Matthaei KI, McKenzie AN, Young IG, Rothenberg ME, Foster PS. Interleukin-13 mediates airways hyperreactivity through the IL-4 receptor-alpha chain and STAT-6 independently of IL-5 and eotaxin. Am J Respir Cell Mol Biol. 2001; 25(4): 522-30 http://www.ncbi.nlm. nih.gov/pubmed/11694459. [Medline] [CrossRef]

74. Chiba Y, Nakazawa S, Todoroki M, Shinozaki K, Sakai H, Misawa M. Interleukin-13 augments bronchial smooth muscle contractility with an up-regulation of RhoA protein. Am J Respir Cell Mol Biol. 2009; 40(2): 159-67 http://www.ncbi.nlm.nih.gov/pubmed/18688040. [Medline] [CrossRef]

75. Barnes PJ. Mechanisms of action of glucocorticoids in asthma. Am J Respir Crit Care Med. 1996; 154(2 Pt 2): S21-6 discussion S26-7 http://www.ncbi.nlm.nih.gov/pubmed/8756783. [Medline] [CrossRef]

76. Chiba Y, Goto K, Hirahara M, Sakai H, Misawa M. Glucocorticoids ameliorate antigen-induced bronchial smooth muscle hyperresponsiveness by inhibiting upregulation of RhoA in rats. J Pharmacol Sci. 2008; 106(4): 615-25 http://www.ncbi.nlm.nih.gov/pubmed/18391481. [Medline] [CrossRef]

77. Kang BN, Tirumurugaan KG, Deshpande DA, Amrani Y, Panettieri RA, Walseth TF, Kannan MS. Transcriptional regulation of CD38 expression by tumor necrosis factor-alpha in human airway smooth muscle cells: role of NF-kappaB and sensitivity to glucocorticoids. FASEB J. 2006; 20(7): 1000-2 http:// www.ncbi.nlm.nih.gov/pubmed/16571778. [Medline] [CrossRef]

78. Tirumurugaan KG, Kang BN, Panettieri RA, Foster DN, Walseth TF, Kannan MS. Regulation of the cd38 promoter in human airway smooth muscle cells by TNF-alpha and dexamethasone. Respir Res. 
2008; 9: 26 http://www.ncbi.nlm.nih.gov/pubmed/18341691. [Medline] [CrossRef]

79. Zhu YM, Bradbury DA, Pang L, Knox AJ. Transcriptional regulation of interleukin (IL)-8 by bradykinin in human airway smooth muscle cells involves prostanoid-dependent activation of AP-1 and nuclear factor (NF)-IL-6 and prostanoid-independent activation of NF-kappaB. J Biol Chem. 2003; 278(31): 29366-75 http://www.ncbi.nlm.nih.gov/pubmed/12748173. [Medline] [CrossRef]

80. Goto K, Chiba Y, Sakai H, Misawa M. Mechanism of inhibitory effect of prednisolone on RhoA upregulation in human bronchial smooth muscle cells. Biol Pharm Bull. 2010; 33(4): 710-3 http://www.ncbi. nlm.nih.gov/pubmed/20410611. [Medline] [CrossRef]

81. Xu P, Guo M, Hay BA. MicroRNAs and the regulation of cell death. Trends Genet. 2004; 20(12): 617-24 https://www.ncbi.nlm.nih.gov/pubmed/15522457. [Medline] [CrossRef]

82. Cheng AM, Byrom MW, Shelton J, Ford LP. Antisense inhibition of human miRNAs and indications for an involvement of miRNA in cell growth and apoptosis. Nucleic Acids Res. 2005; 33(4): 1290-7 https:// www.ncbi.nlm.nih.gov/pubmed/15741182. [Medline] [CrossRef]

83. Felli N, Fontana L, Pelosi E, Botta R, Bonci D, Facchiano F, Liuzzi F, Lulli V, Morsilli O, Santoro S, Valtieri M, Calin GA, Liu CG, Sorrentino A, Croce CM, Peschle C. MicroRNAs 221 and 222 inhibit normal erythropoiesis and erythroleukemic cell growth via kit receptor down-modulation. Proc Natl Acad Sci USA. 2005; 102(50): 18081-6 https://www.ncbi.nlm.nih.gov/pubmed/16330772. [Medline] [CrossRef]

84. Dresios J, Aschrafi A, Owens GC, Vanderklish PW, Edelman GM, Mauro VP. Cold stress-induced protein Rbm3 binds 60S ribosomal subunits, alters microRNA levels, and enhances global protein synthesis. Proc Natl Acad Sci USA. 2005; 102(6): 1865-70 https://www.ncbi.nlm.nih.gov/pubmed/15684048. [Medline] [CrossRef]

85. Guo H, Ingolia NT, Weissman JS, Bartel DP. Mammalian microRNAs predominantly act to decrease target mRNA levels. Nature. 2010; 466(7308): 835-40 https://www.ncbi.nlm.nih.gov/pubmed/20703300. [Medline] [CrossRef]

86. Kang H, Davis-Dusenbery BN, Nguyen PH, Lal A, Lieberman J, Van Aelst L, Lagna G, Hata A. Bone morphogenetic protein 4 promotes vascular smooth muscle contractility by activating microRNA-21 (miR-21), which down-regulates expression of family of dedicator of cytokinesis (DOCK) proteins. J Biol Chem. 2012; 287(6): 3976-86 https://www.ncbi.nlm.nih.gov/pubmed/22158624. [Medline] [CrossRef]

87. Williams KC, Renthal NE, Gerard RD, Mendelson CR. The microRNA (miR)-199a/214 cluster mediates opposing effects of progesterone and estrogen on uterine contractility during pregnancy and labor. Mol Endocrinol. 2012; 26(11): 1857-67 https://www.ncbi.nlm.nih.gov/pubmed/22973051. [Medline] [CrossRef]

88. Carè A, Catalucci D, Felicetti F, Bonci D, Addario A, Gallo P, Bang ML, Segnalini P, Gu Y, Dalton ND, Elia L, Latronico MV, Høydal M, Autore C, Russo MA, Dorn GW 2nd, Ellingsen O, Ruiz-Lozano P, Peterson KL, Croce CM, Peschle C, Condorelli G. MicroRNA-133 controls cardiac hypertrophy. Nat Med. 2007; 13(5): 613-8 http://www.ncbi.nlm.nih.gov/pubmed/17468766. [Medline] [CrossRef]

89. Rehmsmeier M, Steffen P, Hochsmann M, Giegerich R. Fast and effective prediction of microRNA/target duplexes. RNA. 2004; 10(10): 1507-17 http://www.ncbi.nlm.nih.gov/pubmed/15383676. [Medline] [CrossRef]

90. Chiba Y, Tanabe M, Goto K, Sakai H, Misawa M. Down-regulation of miR-133a contributes to upregulation of Rhoa in bronchial smooth muscle cells. Am J Respir Crit Care Med. 2009; 180(8): 713-9 http://www.ncbi.nlm.nih.gov/pubmed/19644046. [Medline] [CrossRef]

91. Chiba Y, Todoroki M, Nishida Y, Tanabe M, Misawa M. A novel STAT6 inhibitor AS1517499 ameliorates antigen-induced bronchial hypercontractility in mice. Am J Respir Cell Mol Biol. 2009; 41(5): 516-24 http://www.ncbi.nlm.nih.gov/pubmed/19202006. [Medline] [CrossRef]

92. Eto M, Ohmori T, Suzuki M, Furuya K, Morita F. A novel protein phosphatase-1 inhibitory protein 
potentiated by protein kinase C. Isolation from porcine aorta media and characterization. J Biochem. 1995; 118(6): 1104-7 http://www.ncbi.nlm.nih.gov/pubmed/8720121. [Medline] [CrossRef]

93. Woodsome TP, Eto M, Everett A, Brautigan DL, Kitazawa T. Expression of CPI-17 and myosin phosphatase correlates with $\mathrm{Ca}(2+)$ sensitivity of protein kinase $\mathrm{C}$-induced contraction in rabbit smooth muscle. J Physiol. 2001; 535(Pt 2): 553-64 http://www.ncbi.nlm.nih.gov/pubmed/11533144. [Medline] [CrossRef]

94. Kitazawa T, Eto M, Woodsome TP, Khalequzzaman M. Phosphorylation of the myosin phosphatase targeting subunit and CPI-17 during $\mathrm{Ca}^{2+}$ sensitization in rabbit smooth muscle. J Physiol. 2003; 546(Pt 3): 879-89 http://www.ncbi.nlm.nih.gov/pubmed/12563012. [Medline] [CrossRef]

95. Dimopoulos GJ, Semba S, Kitazawa K, Eto M, Kitazawa T. $\mathrm{Ca}^{2+}$-dependent rapid $\mathrm{Ca}^{2+}$ sensitization of contraction in arterial smooth muscle. Circ Res. 2007; 100(1): 121-9 https://www.ncbi.nlm.nih.gov/ pubmed/17158339. [Medline] [CrossRef]

96. Takahashi R, Nishimura J, Hirano K, Seki N, Naito S, Kanaide H. $\mathrm{Ca}^{2+}$ sensitization in contraction of human bladder smooth muscle. J Urol. 2004; 172(2): 748-52 https://www.ncbi.nlm.nih.gov/ pubmed/15247775. [Medline] [CrossRef]

97. Ohama T, Hori M, Sato K, Ozaki H, Karaki H. Chronic treatment with interleukin-lbeta attenuates contractions by decreasing the activities of CPI-17 and MYPT-1 in intestinal smooth muscle. J Biol Chem. 2003; 278(49): 48794-804 https://www.ncbi.nlm.nih.gov/pubmed/14512413. [Medline] [CrossRef]

98. Ihara E, Chappellaz M, Turner SR, MacDonald JA. The contribution of protein kinase C and CPI-17 signaling pathways to hypercontractility in murine experimental colitis. Neurogastroenterol Motil. 2012; 24(1): e15-26 https://www.ncbi.nlm.nih.gov/pubmed/22093175. [Medline] [CrossRef]

99. Ozaki H, Yasuda K, Kim YS, Egawa M, Kanzaki H, Nakazawa H, Hori M, Seto M, Karaki H. Possible role of the protein kinase C/CPI-17 pathway in the augmented contraction of human myometrium after gestation. Br J Pharmacol. 2003; 140(7): 1303-12 https:/www.ncbi.nlm.nih.gov/pubmed/14581181. [Medline] [CrossRef]

100. Sakai H, Hirano T, Takeyama H, Chiba Y, Misawa M. Acetylcholine-induced phosphorylation of CPI-17 in rat bronchial smooth muscle: the roles of Rho-kinase and protein kinase C. Can J Physiol Pharmacol. 2005; 83(4): 375-81 https://www.ncbi.nlm.nih.gov/pubmed/15877112. [Medline] [CrossRef]

101. Sakai H, Hirano T, Chiba Y, Misawa M. Acetylcholine-induced phosphorylation and membrane translocation of CPI-17 in bronchial smooth muscle of rats. Am J Physiol Lung Cell Mol Physiol. 2005; 289(6): L925-30 https://www.ncbi.nlm.nih.gov/pubmed/16040632. [Medline] [CrossRef]

102. Sakai H, Chiba Y, Misawa M. Role of Rho kinase in endothelin-1-induced phosphorylation of CPI-17 in rat bronchial smooth muscle. Pulm Pharmacol Ther. 2007; 20(6): 734-9 http://www.ncbi.nlm.nih.gov/ pubmed/17071121. [Medline] [CrossRef]

103. Sakai H, Chiba Y, Hirano T, Misawa M. Possible involvement of CPI-17 in augmented bronchial smooth muscle contraction in antigen-induced airway hyper-responsive rats. Mol Pharmacol. 2005; 68(1): 14551 http://www.ncbi.nlm.nih.gov/pubmed/15814573. [Medline] [CrossRef]

104. Sakai H, Kurihara Y, Hashimoto Y, Chiba Y, Misawa M. Augmented PDBu-mediated contraction of bronchial smooth muscle of mice with antigen-induced airway hyperresponsiveness. J Smooth Muscle Res. 2010; 46(5): 259-66 http://www.ncbi.nlm.nih.gov/pubmed/21187674. [Medline] [CrossRef]

105. Kitazawa T, Eto M, Woodsome TP, Brautigan DL. Agonists trigger G protein-mediated activation of the CPI-17 inhibitor phosphoprotein of myosin light chain phosphatase to enhance vascular smooth muscle contractility. J Biol Chem. 2000; 275(14): 9897-900 http://www.ncbi.nlm.nih.gov/pubmed/10744661. [Medline] [CrossRef]

106. Goto K, Chiba Y, Sakai H, Misawa M. Glucocorticoids inhibited airway hyperresponsiveness through downregulation of CPI-17 in bronchial smooth muscle. Eur J Pharmacol. 2008; 591(1-3): 231-6 http:// www.ncbi.nlm.nih.gov/pubmed/18577381. [Medline] [CrossRef]

107. D’Alonzo GE, Barst RJ, Ayres SM, Bergofsky EH, Brundage BH, Detre KM, Fishman AP, Goldring 
RM, Groves BM, Kernis JT, et al. Survival in patients with primary pulmonary hypertension. Results from a national prospective registry. Ann Intern Med. 1991; 115(5): 343-9 http://www.ncbi.nlm.nih.gov/ pubmed/1863023. [Medline] [CrossRef]

108. Korsholm K, Andersen A, Kirkfeldt RE, Hansen KN, Mellemkjær S, Nielsen-Kudsk JE. Survival in an incident cohort of patients with pulmonary arterial hypertension in Denmark. Pulm Circ. 2015; 5(2): 364-9 https://www.ncbi.nlm.nih.gov/pubmed/26064463. [Medline] [CrossRef]

109. Montani D, O’Callaghan DS, Savale L, Jaïs X, Yaïci A, Maitre S, Dorfmuller P, Sitbon O, Simonneau G, Humbert M. Pulmonary veno-occlusive disease: recent progress and current challenges. Respir Med. 2010; 104(Suppl 1): S23-32 https://www.ncbi.nlm.nih.gov/pubmed/20956152. [Medline] [CrossRef]

110. Hervé P, Lebrec D, Brenot F, Simonneau G, Humbert M, Sitbon O, Duroux P. Pulmonary vascular disorders in portal hypertension. Eur Respir J. 1998; 11(5): 1153-66 https://www.ncbi.nlm.nih.gov/ pubmed/9648972. [Medline] [CrossRef]

111. Speich R, Jenni R, Opravil M, Pfab M, Russi EW. Primary pulmonary hypertension in HIV infection. Chest. 1991; 100(5): 1268-71 https:/www.ncbi.nlm.nih.gov/pubmed/1935280. [Medline] [CrossRef]

112. Coplan NL, Shimony RY, Ioachim HL, Wilentz JR, Posner DH, Lipschitz A, Ruden RA, Bruno MS, Sherrid MV, Gaetz H, et al. Primary pulmonary hypertension associated with human immunodeficiency viral infection. Am J Med. 1990; 89(1): 96-9 https://www.ncbi.nlm.nih.gov/pubmed/2368798. [Medline] [CrossRef]

113. Brenot F, Herve P, Petitpretz P, Parent F, Duroux P, Simonneau G. Primary pulmonary hypertension and fenfluramine use. Br Heart J. 1993; 70(6): 537-41 https://www.ncbi.nlm.nih.gov/pubmed/8280518. [Medline] [CrossRef]

114. McMurray J, Bloomfield P, Miller HC. Irreversible pulmonary hypertension after treatment with fenfluramine. Br Med J (Clin Res Ed). 1986; 292(6515): 239-40 https://www.ncbi.nlm.nih.gov/ pubmed/3081088. [Medline] [CrossRef]

115. Machado RD, Eickelberg O, Elliott CG, Geraci MW, Hanaoka M, Loyd JE, Newman JH, Phillips JA 3rd, Soubrier F, Trembath RC, Chung WK. Genetics and genomics of pulmonary arterial hypertension. J Am Coll Cardiol. 2009; 54(1 Suppl): S32-42 https://www.ncbi.nlm.nih.gov/pubmed/19555857. [Medline] [CrossRef]

116. Hoeper MM, McLaughlin VV, Dalaan AM, Satoh T, Galiè N. Treatment of pulmonary hypertension. Lancet Respir Med. 2016; 4(4): 323-36 https://www.ncbi.nlm.nih.gov/pubmed/26975811. [Medline] [CrossRef]

117. Humbert M, Sitbon O, Simonneau G. Treatment of pulmonary arterial hypertension. N Engl J Med. 2004; 351(14): 1425-36 https://www.ncbi.nlm.nih.gov/pubmed/15459304. [Medline] [CrossRef]

118. Rubin LJ. Primary pulmonary hypertension. N Engl J Med. 1997; 336(2): 111-7 https://www.ncbi.nlm. nih.gov/pubmed/8988890. [Medline] [CrossRef]

119. Rubin LJ. Primary pulmonary hypertension. Chest. 1993; 104(1): 236-50 https://www.ncbi.nlm.nih. gov/pubmed/8325077. [Medline] [CrossRef]

120. Abe K, Toba M, Alzoubi A, Ito M, Fagan KA, Cool CD, Voelkel NF, McMurtry IF, Oka M. Formation of plexiform lesions in experimental severe pulmonary arterial hypertension. Circulation. 2010; 121(25): 2747-54 https://www.ncbi.nlm.nih.gov/pubmed/20547927. [Medline] [CrossRef]

121. Ranchoux B, Antigny F, Rucker-Martin C, Hautefort A, Péchoux C, Bogaard HJ, Dorfmüller P, Remy S, Lecerf F, Planté S, Chat S, Fadel E, Houssaini A, Anegon I, Adnot S, Simonneau G, Humbert M, CohenKaminsky S, Perros F. Endothelial-to-mesenchymal transition in pulmonary hypertension. Circulation. 2015; 131(11): 1006-18 https://www.ncbi.nlm.nih.gov/pubmed/25593290. [Medline] [CrossRef]

122. Lüscher TF, Boulanger CM, Dohi Y, Yang ZH. Endothelium-derived contracting factors. Hypertension. 1992; 19(2): 117-30 https://www.ncbi.nlm.nih.gov/pubmed/1737645. [Medline] [CrossRef]

123. Cai H, Harrison DG. Endothelial dysfunction in cardiovascular diseases: the role of oxidant stress. Circ 
Res. 2000; 87(10): 840-4 https://www.ncbi.nlm.nih.gov/pubmed/11073878. [Medline] [CrossRef]

124. Pietra GG, Edwards WD, Kay JM, Rich S, Kernis J, Schloo B, Ayres SM, Bergofsky EH, Brundage $\mathrm{BH}$, Detre KM, et al. Histopathology of primary pulmonary hypertension. A qualitative and quantitative study of pulmonary blood vessels from 58 patients in the National Heart, Lung, and Blood Institute, Primary Pulmonary Hypertension Registry. Circulation. 1989; 80(5): 1198-206 https://www.ncbi.nlm. nih.gov/pubmed/2805258. [Medline] [CrossRef]

125. Arciniegas E, Ponce L, Hartt Y, Graterol A, Carlini RG. Intimal thickening involves transdifferentiation of embryonic endothelial cells. Anat Rec. 2000; 258(1): 47-57 https://www.ncbi.nlm.nih.gov/ pubmed/10603448. [Medline] [CrossRef]

126. Arciniegas E, Frid MG, Douglas IS, Stenmark KR. Perspectives on endothelial-to-mesenchymal transition: potential contribution to vascular remodeling in chronic pulmonary hypertension. Am J Physiol Lung Cell Mol Physiol. 2007; 293(1): L1-8 https://www.ncbi.nlm.nih.gov/pubmed/17384082. [Medline] [CrossRef]

127. Lee SD, Shroyer KR, Markham NE, Cool CD, Voelkel NF, Tuder RM. Monoclonal endothelial cell proliferation is present in primary but not secondary pulmonary hypertension. J Clin Invest. 1998; 101(5): 927-34 https://www.ncbi.nlm.nih.gov/pubmed/9486960. [Medline] [CrossRef]

128. Qiao L, Nishimura T, Shi L, Sessions D, Thrasher A, Trudell JR, Berry GJ, Pearl RG, Kao PN. Endothelial fate mapping in mice with pulmonary hypertension. Circulation. 2014; 129(6): 692-703 https:// www.ncbi.nlm.nih.gov/pubmed/24201301. [Medline] [CrossRef]

129. Fraisl P, Mazzone M, Schmidt T, Carmeliet P. Regulation of angiogenesis by oxygen and metabolism. Dev Cell. 2009; 16(2): 167-79 https://www.ncbi.nlm.nih.gov/pubmed/19217420. [Medline] [CrossRef]

130. Davies PF. Flow-mediated endothelial mechanotransduction. Physiol Rev. 1995; 75(3): 519-60 https:// www.ncbi.nlm.nih.gov/pubmed/7624393. [Medline] [CrossRef]

131. Blobe GC, Schiemann WP, Lodish HF. Role of transforming growth factor beta in human disease. N Engl J Med. 2000; 342(18): 1350-8 https://www.ncbi.nlm.nih.gov/pubmed/10793168. [Medline] [CrossRef]

132. Medina C, Santos-Martinez MJ, Santana A, Paz-Cabrera MC, Johnston MJ, Mourelle M, Salas A, Guarner F. Transforming growth factor-beta type 1 receptor (ALK5) and Smad proteins mediate TIMP1 and collagen synthesis in experimental intestinal fibrosis. J Pathol. 2011; 224(4): 461-72 https://www. ncbi.nlm.nih.gov/pubmed/21465486. [Medline] [CrossRef]

133. Biancheri P, Giuffrida P, Docena GH, MacDonald TT, Corazza GR, Di Sabatino A. The role of transforming growth factor (TGF)- $\beta$ in modulating the immune response and fibrogenesis in the gut. Cytokine Growth Factor Rev. 2014; 25(1): 45-55 https://www.ncbi.nlm.nih.gov/pubmed/24332927. [Medline] [CrossRef]

134. Richter A, Yeager ME, Zaiman A, Cool CD, Voelkel NF, Tuder RM. Impaired transforming growth factor-beta signaling in idiopathic pulmonary arterial hypertension. Am J Respir Crit Care Med. 2004; 170(12): 1340-8 https://www.ncbi.nlm.nih.gov/pubmed/15361368. [Medline] [CrossRef]

135. Böttner M, Krieglstein K, Unsicker K. The transforming growth factor-betas: structure, signaling, and roles in nervous system development and functions. J Neurochem. 2000; 75(6): 2227-40 https://www. ncbi.nlm.nih.gov/pubmed/11080174. [Medline] [CrossRef]

136. Risau W. Mechanisms of angiogenesis. Nature. 1997; 386(6626): 671-4 https://www.ncbi.nlm.nih.gov/ pubmed/9109485. [Medline] [CrossRef]

137. Carmeliet P. Mechanisms of angiogenesis and arteriogenesis. Nat Med. 2000; 6(4): 389-95 https://www. ncbi.nlm.nih.gov/pubmed/10742145. [Medline] [CrossRef]

138. Hugo H, Ackland ML, Blick T, Lawrence MG, Clements JA, Williams ED, Thompson EW. Epithelialmesenchymal and mesenchymal — epithelial transitions in carcinoma progression. J Cell Physiol. 2007; 213(2): 374-83 https://www.ncbi.nlm.nih.gov/pubmed/17680632. [Medline] [CrossRef] 
139. Davis FM, Azimi I, Faville RA, Peters AA, Jalink K, Putney JW Jr, Goodhill GJ, Thompson EW, Roberts-Thomson SJ, Monteith GR. Induction of epithelial-mesenchymal transition (EMT) in breast cancer cells is calcium signal dependent. Oncogene. 2014; 33(18): 2307-16 https://www.ncbi.nlm.nih. gov/pubmed/23686305. [Medline] [CrossRef]

140. Guignabert C, Tu L, Le Hiress M, Ricard N, Sattler C, Seferian A, Huertas A, Humbert M, Montani D. Pathogenesis of pulmonary arterial hypertension: lessons from cancer. Eur Respir Rev. 2013; 22(130): 543-51 https://www.ncbi.nlm.nih.gov/pubmed/24293470. [Medline] [CrossRef]

141. Lane KB, Machado RD, Pauciulo MW, Thomson JR, Phillips JA 3rd, Loyd JE, Nichols WC, Trembath $\mathrm{RC}$, International PPH Consortium Heterozygous germline mutations in BMPR2, encoding a TGF-beta receptor, cause familial primary pulmonary hypertension. Nat Genet. 2000; 26(1): 81-4 https://www. ncbi.nlm.nih.gov/pubmed/10973254. [Medline] [CrossRef]

142. Stenmark KR, Fagan KA, Frid MG. Hypoxia-induced pulmonary vascular remodeling: cellular and molecular mechanisms. Circ Res. 2006; 99(7): 675-91 https://www.ncbi.nlm.nih.gov/pubmed/17008597. [Medline] [CrossRef]

143. Zheng J. Molecular mechanism of TRP channels. Compr Physiol. 2013; 3(1): 221-42 https://www.ncbi. nlm.nih.gov/pubmed/23720286. [Medline]

144. Inoue R. TRP channels as a newly emerging non-voltage-gated $\mathrm{CA}^{2+}$ entry channel superfamily. Curr Pharm Des. 2005; 11(15): 1899-914 http://www.ncbi.nlm.nih.gov/pubmed/15974967. [Medline] [CrossRef]

145. Inoue R, Jensen LJ, Shi J, Morita H, Nishida M, Honda A, Ito Y. Transient receptor potential channels in cardiovascular function and disease. Circ Res. 2006; 99(2): 119-31 https://www.ncbi.nlm.nih.gov/ pubmed/16857972. [Medline] [CrossRef]

146. Inoue R, Honda A, Lin H. [New frontier for the pathophysiology of TRP channels in cardiovascular system: cardiovascular remodeling and TRP channels]. Tanpakushitsu Kakusan Koso. 2008; 53(7): 844-53 (in Japanese) http://www.ncbi.nlm.nih.gov/pubmed/18536347. [Medline]

147. Numata T, Takahashi K, Inoue R. "TRP inflammation” relationship in cardiovascular system. Semin Immunopathol. 2016; 38(3): 339-56 https://www.ncbi.nlm.nih.gov/pubmed/26482920. [Medline] [CrossRef]

148. Clapham DE, Runnels LW, Strübing C. The TRP ion channel family. Nat Rev Neurosci. 2001; 2(6): 387-96 https://www.ncbi.nlm.nih.gov/pubmed/11389472. [Medline] [CrossRef]

149. Earley S, Brayden JE. Transient receptor potential channels in the vasculature. Physiol Rev. 2015; 95(2): 645-90 https://www.ncbi.nlm.nih.gov/pubmed/25834234. [Medline] [CrossRef]

150. Fujiwara Y, Minor DL Jr. X-ray crystal structure of a TRPM assembly domain reveals an antiparallel fourstranded coiled-coil. J Mol Biol. 2008; 383(4): 854-70 https://www.ncbi.nlm.nih.gov/pubmed/18782578. [Medline] [CrossRef]

151. Liao M, Cao E, Julius D, Cheng Y. Structure of the TRPV1 ion channel determined by electron cryomicroscopy. Nature. 2013; 504(7478): 107-12 https://www.ncbi.nlm.nih.gov/pubmed/24305160. [Medline] [CrossRef]

152. Yu Y, Fantozzi I, Remillard CV, Landsberg JW, Kunichika N, Platoshyn O, Tigno DD, Thistlethwaite PA, Rubin LJ, Yuan JX. Enhanced expression of transient receptor potential channels in idiopathic pulmonary arterial hypertension. Proc Natl Acad Sci USA. 2004; 101(38): 13861-6 https://www.ncbi.nlm. nih.gov/pubmed/15358862. [Medline] [CrossRef]

153. Malczyk M, Veith C, Fuchs B, Hofmann K, Storch U, Schermuly RT, Witzenrath M, Ahlbrecht K, Fecher-Trost C, Flockerzi V, Ghofrani HA, Grimminger F, Seeger W, Gudermann T, Dietrich A, Weissmann N. Classical transient receptor potential channel 1 in hypoxia-induced pulmonary hypertension. Am J Respir Crit Care Med. 2013; 188(12): 1451-9 https://www.ncbi.nlm.nih.gov/pubmed/24251695. [Medline] [CrossRef]

154. Martin E, Dahan D, Cardouat G, Gillibert-Duplantier J, Marthan R, Savineau JP, Ducret T. Involvement 
of TRPV1 and TRPV4 channels in migration of rat pulmonary arterial smooth muscle cells. Pflugers Arch. 2012; 464(3): 261-72 https://www.ncbi.nlm.nih.gov/pubmed/22820913. [Medline] [CrossRef]

155. Parpaite T, Cardouat G, Mauroux M, Gillibert-Duplantier J, Robillard P, Quignard JF, Marthan R, Savineau JP, Ducret T. Effect of hypoxia on TRPV1 and TRPV4 channels in rat pulmonary arterial smooth muscle cells. Pflugers Arch. 2016; 468(1): 111-30 https://www.ncbi.nlm.nih.gov/pubmed/25799977. [Medline] [CrossRef]

156. Du J, Xie J, Zhang Z, Tsujikawa H, Fusco D, Silverman D, Liang B, Yue L. TRPM7-mediated $\mathrm{Ca}^{2+}$ signals confer fibrogenesis in human atrial fibrillation. Circ Res. 2010; 106(5): 992-1003 https://www. ncbi.nlm.nih.gov/pubmed/20075334. [Medline] [CrossRef]

157. Inoue K, Xiong ZG. Silencing TRPM7 promotes growth/proliferation and nitric oxide production of vascular endothelial cells via the ERK pathway. Cardiovasc Res. 2009; 83(3): 547-57 https://www.ncbi. nlm.nih.gov/pubmed/19454490. [Medline] [CrossRef]

158. Sarmiento D, Montorfano I, Cáceres M, Echeverría C, Fernández R, Cabello-Verrugio C, Cerda O, Tapia P, Simon F. Endotoxin-induced vascular endothelial cell migration is dependent on TLR4/NF$\kappa \mathrm{B}$ pathway, $\mathrm{NAD}(\mathrm{P}) \mathrm{H}$ oxidase activation, and transient receptor potential melastatin 7 calcium channel activity. Int J Biochem Cell Biol. 2014; 55: 11-23 https://www.ncbi.nlm.nih.gov/pubmed/25130439. [Medline] [CrossRef]

159. Qin X, Yue Z, Sun B, Yang W, Xie J, Ni E, Feng Y, Mahmood R, Zhang Y, Yue L. Sphingosine and FTY720 are potent inhibitors of the transient receptor potential melastatin 7 (TRPM7) channels. Br J Pharmacol. 2013; 168(6): 1294-312 https://www.ncbi.nlm.nih.gov/pubmed/23145923. [Medline] [CrossRef]

160. Thomson A. FTY720 in multiple sclerosis: the emerging evidence of its therapeutic value. Core Evid. 2006; 1(3): 157-67 https://www.ncbi.nlm.nih.gov/pubmed/22500151. [Medline]

161. Chun J, Brinkmann V. A mechanistically novel, first oral therapy for multiple sclerosis: the development of fingolimod (FTY720, Gilenya). Discov Med. 2011; 12(64): 213-28 https://www.ncbi.nlm.nih.gov/ pubmed/21955849. [Medline]

162. Peng Y, Huang K, Shen L, Tao YY, Liu CH. Cultured Mycelium Cordyceps sinensis allevi $\neg$ ates CCl4induced liver inflammation and fibrosis in mice by activating hepatic natural killer cells. Acta Pharmacol Sin. 2016; 37(2): 204-16 https://www.ncbi.nlm.nih.gov/pubmed/26592510. [Medline] [CrossRef]

163. Huang TT, Lai HC, Ko YF, Ojcius DM, Lan YW, Martel J, Young JD, Chong KY. Hirsutella sinensis mycelium attenuates bleomycin-induced pulmonary inflammation and fibrosis in vivo. Sci Rep. 2015; 5: 15282 https://www.ncbi.nlm.nih.gov/pubmed/26497260. [Medline] [CrossRef]

164. Stenmark KR, Meyrick B, Galie N, Mooi WJ, McMurtry IF. Animal models of pulmonary arterial hypertension: the hope for etiological discovery and pharmacological cure. Am J Physiol Lung Cell Mol Physiol. 2009; 297(6): L1013-32 https://www.ncbi.nlm.nih.gov/pubmed/19748998. [Medline] [CrossRef] 